\title{
Structure AND DIVERSITY OF OAK FORESTS IN THE El Tepozteco National Park (Morelos, Mexico)
}

\author{
Sebastián Block and Jorge A. Meave ${ }^{1}$ \\ Departamento de Ecología y Recursos Naturales, Facultad de Ciencias, Universidad Nacional Autónoma de México, \\ México 04510, D.F., México. \\ ${ }^{1}$ Author for correspondence. E-mail: jorge.meave@ciencias.unam.mx
}

\begin{abstract}
Quercus (oak) is among the most speciose and widespread genera occurring in Mexico; paradoxically, the ecological knowledge about Mexican oak forests is meager. Here we describe the floristic composition, diversity, and structure of the terrestrial component of the oak forests of the El Tepozteco National Park (TNP), Central Mexico, and relate their floristic and structural heterogeneity to the geomorphological complexity of the park. We randomly distributed sixty $100-\mathrm{m}^{2}$ plots among six geomorphological units: the lava fields of the Chichinautzin, Suchiooc, Otates (upper and lower) and Oclayuca volcanoes, and the El Tepozteco Range. Vegetation structure and diversity were described by geomorphological unit and for the oak forest as a whole for canopy $(\mathrm{DBH} \geq 2.5 \mathrm{~cm})$ and understory plants. We report 324 vascular plant species recorded in the plots, plus 17 species collected outside the plots (a total of 341 species, 208 genera and 88 families). The family with more species was Asteraceae (57) and the most speciose genus was Salvia (10). Geomorphological units differed in mean species richness per plot (12.0-33.5 species), absolute richness (60-149 species), and species' structural contributions. Structural differences were also observed, but they were not always significant. Quercus rugosa was dominant in Chichinautzin, Suchiooc, and upper Otates; Styrax ramirezii in lower Otates and Oclayuca, and Quercus castanea and Q. obtusata shared dominance in El Tepozteco Range (the unit with the largest overall richness and oak species diversity). The structure and composition of TNP oak forests are highly variable, apparently due to the region's complex geological past. This heterogeneity should guide the conservation and restoration of these forests.
\end{abstract}

Key words: canopy, dominance, geomorphological heterogeneity, floristic richness, natural protected area, primary succession, Quercus, understory, vegetation structure.

Resumen: Quercus (encino, roble) es uno de los géneros con más especies y de distribución más amplia en México; por ello, es paradójico que el conocimiento ecológico de los encinares mexicanos sea tan pobre. En este artículo describimos la composición florística, la diversidad y la estructura del componente terrestre de los encinares del Parque Nacional El Tepozteco (centro de México), así como la relación de estos atributos con la complejidad geomorfológica del parque. Establecimos al azar 60 parcelas de $100 \mathrm{~m}^{2}$ en seis unidades geomorfológicas: los derrames de lava de los volcanes Chichinautzin, Suchiooc, Otates (porciones alta y baja) y Oclayuca, y la Sierra del Tepozteco. Describimos la vegetación por unidad geomorfológica y para todas en conjunto, para las plantas del dosel (DAP $\geq 2.5 \mathrm{~cm}$ ) y del sotobosque por separado. Reportamos 324 especies de plantas vasculares registradas en las parcelas más 17 especies recolectadas fuera de ellas (341 especies, 208 géneros y 88 familias en total). La familia con mayor riqueza fue Asteraceae ( 57 especies) y el género más rico fue Salvia (10 especies). Hubo diferencias entre unidades geomorfológicas en la riqueza promedio por parcela (12.0-33.5 especies), la riqueza total (60-149 especies), y en las contribuciones estructurales de las especies; también observamos diferencias estructurales, pero éstas no siempre fueron significativas. Quercus rugosa fue dominante en Chichinautzin, Suchiooc y la parte alta de Otates, Styrax ramirezii en la parte inferior de Otates y en Oclayuca, mientras que Quercus castanea y Q. obtusata compartieron la dominancia en la Sierra del Tepozteco (la unidad de mayor riqueza de especies, tanto en general como solamente de encinos). La estructura y la composición de los encinares del parque son heterogéneas, aparentemente debido a la complejidad del pasado geológico de la región. Esta heterogeneidad debería guiar la conservación y la restauración de los encinares del parque.

Palabras clave: área natural protegida, dominancia, dosel, estructura de la vegetación, heterogeneidad ambiental, Quercus, riqueza florística, sotobosque, sucesión primaria.

$\mathbf{O}$ ak forests are among the most prominent vegetation types in Laurasian continents. Although the geographical range of oaks (genus Quercus) spreads across the entire North American continent, reaching as far south as Colombia in northern South America (Nixon, 2006), the diversification peak of this plant group is located in Mexico 
(Nixon, 1993; Valencia-A., 2004). In this country, oaks are particularly abundant and diverse in mountainous systems, regardless of whether these occur in the northern arid regions or the hyper-humid ones in southern states like Oaxaca and Chiapas (Nixon, 1993; Meave et al., 2006). Oak forests are not only widely distributed in Mexico, but they are also one of the most species-rich vegetation types in the country (Villaseñor, 2004). Regrettably, oak forests are also highly threatened due to urban and agricultural expansion, and historically due to wood extraction for charcoal production (Luna-José et al., 2003).

Given the large suit of threats faced by oak forests, establishment of natural protected areas has been the major strategy for their conservation, in combination with ex situ plant collections in botanical gardens and arboreta (Oldfield and Eastwood, 2007). Unfortunately, many natural protected areas in Mexico have not prevented forest cover change (Figueroa and Sánchez-Cordero, 2008). A likely reason for such ineffectiveness is the failure to implement robust management plans based on high quality biological, ecological and socio-economic knowledge. An example of this situation is the El Tepozteco National Park (TNP), whose complex vegetation cover is insufficiently known to-date, despite its close proximity to numerous research centers and universities with strong academic groups conducting botanical research. Among the various vegetation types protected within its territory, oak forests are of particular interest, because of their large extent across a highly heterogeneous landscape and the persistent human disturbance they are subjected to (Vega-Guzmán et al., 2008).

In response to the urgent need for accurate and reliable information on the magnitude and composition of the biodiversity thriving in Mexican national parks, and in order to provide the necessary tools for a more appropriate management of its resources, the objective of this study was to describe and characterize the floristic composition, plant diversity, and forest structure of the oak forests in the TNP. Also, we performed a preliminary analysis of the relationship between the geomorphological heterogeneity of the area and the floristic and structural heterogeneity of its oak forests.

\section{Study area}

Location and physical environment. The TNP covers an area of 23,268 ha, most of which lies in the northernmost portion of the state of Morelos, while a small section is located within the Federal District (Figure 1). The park is located in the southeastern sector of the Trans-Mexican Neo-Volcanic Belt, a physiographic province $1,000 \mathrm{~km}$ long and between 20 and $200 \mathrm{~km}$ wide that spans across Mexico between $19^{\circ}$ and $21^{\circ}$ northern latitude (Ferrusquía-Villafranca, 1993).

Topography in the TNP is complex, as it encompasses an elevational gradient from 1,380 to $3,350 \mathrm{~m}$ a.s.l. The highest peak in the park is the summit of Chichinautzin volcano, at its north-western end. Within the park's boundaries several other volcanoes occur, all of them being monogenetic and less than 40,000 yr old (Márquez et al., 1999). These volcanoes sit on a plateau at $c a .3,100 \mathrm{~m}$ a.s.l., and their cones reach elevations between 50 and $150 \mathrm{~m}$ above the surrounding terrain. South of the volcanoes the terrain descends abruptly to a valley at $c a$. 1,500 $\mathrm{m}$ a.s.l. In the central part of the park the El Tepozteco Range is located; this is a distinct geomorphological unit due to its prominent cliffs and ravines, which provide a variety of suitable microhabitats for oak forest development. With the exception of some limestone of Late Cretaceous age in the southern portion of the TNP, most of its surface geology derives from the volcanic activity that has taken place in the region during the Cenozoic Era (Ávila-Bravo, 1998). The El Tepozteco Range is predominantly composed of lahars and fluvial deposits from the Oligocene-Miocene (Ávila-Bravo, 1998). North of this physiographic unit, a mosaic of lava fields is found whose ages vary between $c a$. 1,800 and 40,000 years, all of which are the result of eruptive events of the abovementioned volcanoes (Espinasa-Pereña, 1999; Márquez et al., 1999; Siebe et al., 2004).

Given its large elevational gradient, TNP comprises a large climatic variability. Regrettably, there is only one meteorological station in the park at 2,366 m a.s.l., roughly in the middle of the elevational gradient (Figure 1C). There, the average total annual precipitation from 1981 to 1996 was $2,099.5 \mathrm{~mm}$ (highly concentrated from June to October), while the mean annual temperature was $15.6^{\circ} \mathrm{C}$ (INEGI, 2003). Winter precipitation accounts for less than $5 \%$ of total annual rainfall. In the elevational belt where most of the park's oak forests occur (2,000-3,000 $\mathrm{m}$ a.s.1.) the climate type is classified as $\mathrm{C}\left(\mathrm{w}_{2}\right.$ ")(w)big in the Köppen-Geiger system (Kottek et al., 2006), i.e., temperate sub-humid.

Vegetation. The climatic variation associated with the elevational gradient, along with the complex topography, defines the presence of a diverse array of plant communities in the TNP. In the park, a gradual vegetation transition occurs from a seasonally dry tropical forest in the lowest parts to sub-alpine grasslands (known as zacatonales) in the craters of the highest volcanoes. Between these two extremes there are different types of temperate forests (i.e., thriving in $\mathrm{C}$ climate, sensu Köppen-Geiger), among which oak forests occur over a relatively wide range of climatic, topographic and geomorphological variation. Oak forests abut other vegetation types with which they share diffuse borders. The most prominent of these is pine forest, with pine dominance rising smoothly with increasing elevation. Also, within the oak forests there are patches of xerophytic scrub found in the youngest lava fields, and in the lowest part of the altitudinal range of oaks several species typical of seasonally dry tropical forest are common. 


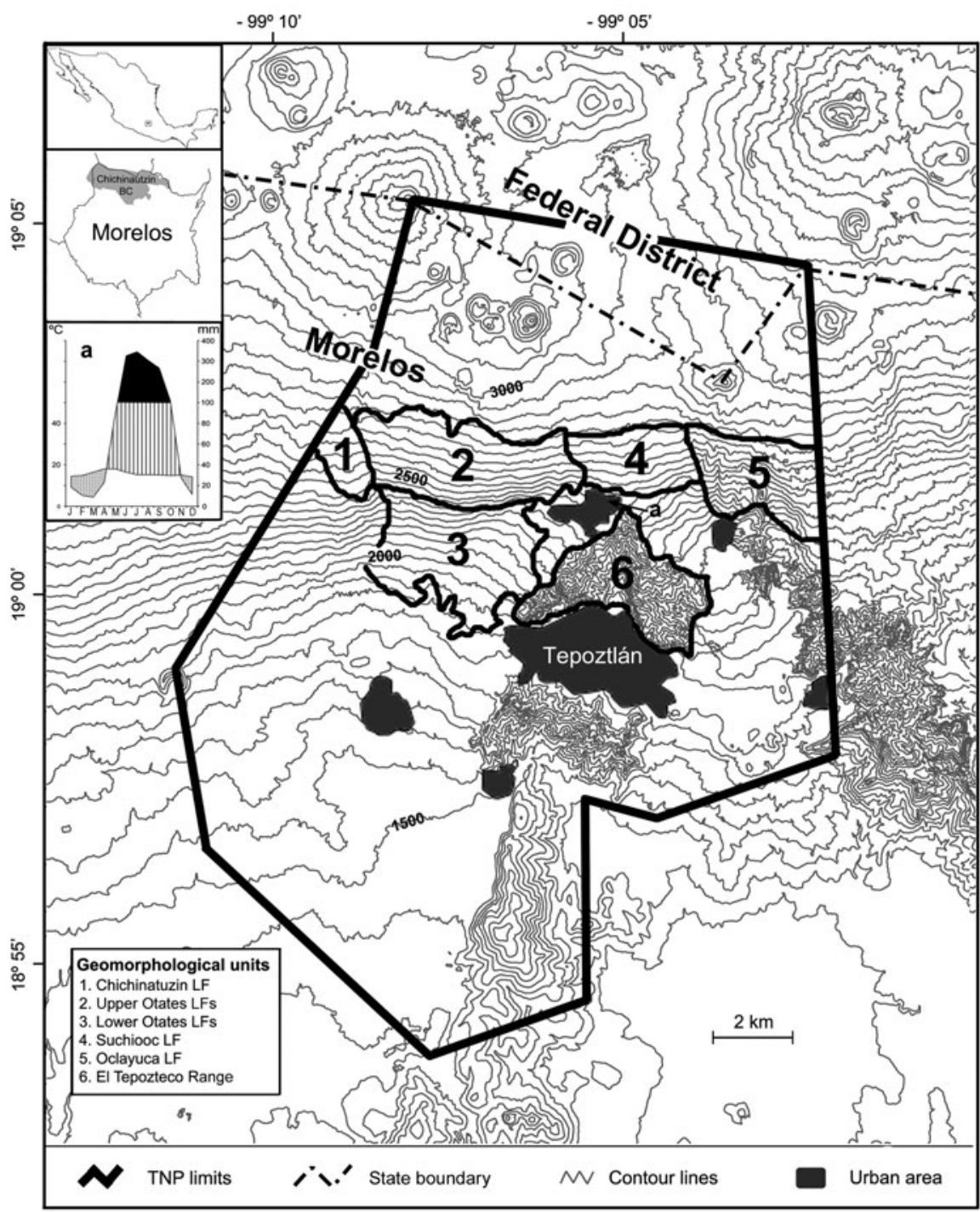

Figure 1. Location, limits and topography of the El Tepozteco National Park, Mexico. Both the geomorphological units recognized in this study and the climate diagram from the San Juan Tlacotenco meteorological station (indicated with the letter a) are shown (INEGI, 2003).

Contour lines represent $50 \mathrm{~m}$ altitude increments. Main urban areas in the TNP are shown in gray. $\mathrm{LF}(\mathrm{s})=\operatorname{lava} f(i e l d(\mathrm{~s})$.

Botanists have been long interested in the flora and vegetation of the TNP. However, so far, they limited their studies to floristic notes (e.g., Hernández, 1945; Reko, 1945) and vegetation descriptions covering small areas only (e.g., Espinosa-Garduño, 1962). For a detailed description of the park's vegetation the reader is referred to the draft of the TNP Management Program (available at: www.conanp.gob. $\mathrm{mx} / \mathrm{anp} / \mathrm{consulta/Anteproyecto16may08.pdf)}$ and a study by Vega-Guzmán et al. (2008).

\section{Methods}

Based on geomorphological information reported by Espinasa-Pereña (1999) and on exploratory surveys in the area, we identified six relatively homogeneous geomorphological units in the TNP in which oak forests are found. Among them, the Chichinautzin lava field is the youngest, with an age of $c a .1,800$ years (Siebe et al., 2004). The other units correspond to lava fields of the Suchiooc, Otates and Oclayuca volcanoes (with ages between 10 and 40 thousand years), and to the El Tepozteco Range (about 20 million years old). Actually, Otates is a complex of volcanoes of similar ages; their lava fields are indistinguishable from each other. Thus, they were considered as a single geomorphological unit. Yet because of their broad elevational gradient, the Otates lava fields were divided into two units (upper and lower), with the 2,400 $\mathrm{m}$ contour line being the limit between them. In each geomorphological unit, we randomly located ten $100-\mathrm{m}^{2}(10 \times 10 \mathrm{~m})$ sampling plots. This resulted in a total of 60 sampling plots.

We conducted field work during October and November of 2010 and 2011, because many plant species typical of 
Mexican temperate forests bear reproductive structures during those months (Cornejo-Tenorio and Ibarra-Manríquez, 2007). For measuring and analyzing forest structure, terrestrial plants rooted inside the plot were classified in one of two strata: plants with a diameter at breast height (DBH, at $1.3 \mathrm{~m}$ ) $\geq 2.5 \mathrm{~cm}$, which we named 'canopy', and plants with a DBH $<2.5 \mathrm{~cm}$, which we named 'understory'. We did not use a minimum height inclusion criterion because that would have led to the exclusion from the study of a considerable number of creeping and small-sized species. However, we did exclude seedlings (plants with cotiledonary leaves still present), as their taxonomic identification is often very difficult.

We assessed the cover of understory species in each sampling plot based on the Braun-Blanquet scale modified by van der Maarel (1979), which consists of nine ordinal values representing different ranges of percent cover within the plot. In order to use these ordinal values in numerical analyses, we transformed them with the equation:

$$
\ln C=\frac{(O T V-2)}{1.415}
$$

where $C$ is cover and $O T V$ is the ordinal value (van der Maarel, 2007).

When the stems of canopy individuals branched below $1.3 \mathrm{~m}$, we measured all stems with a $\mathrm{DBH} \geq 2.5 \mathrm{~cm}$. We also measured two perpendicular crown diameters; crown cover was estimated calculating the area of an ellipse based on these diameters. Tree height was calculated with trigonometry based on measurements of observation angle to the top of the crown and distance to the base of the tree (Meave and Pérez-García, 2013).

We collected specimens of all plant species within the plots, which then were identified to species level whenever possible. To this end, we used taxonomic keys [mostly Mickel and Smith (2004) for ferns and Rzedowski and Rzedowski (2005) for spermatophytes], and consulted specialists in different families and groups (Appendix 1). Verification of taxonomic determinations was achieved through comparison of our specimens with herbarium specimens deposited at MEXU [National Herbarium of Mexico, National Autonomous University of Mexico (UNAM), Mexico City]. We prepared a checklist of all identified taxa, organized taxonomically according to Christenhusz et al. (2011) and to the Angiosperm Phylogeny Group III (APG III, 2009).

We constructed smooth species accumulation curves with the Mao Tau procedure and accumulation curves of the effective number of species of $H^{\prime}$ (Jost, 2006); $H^{\prime}$ is Shannon index and was calculated with the following formula:

$$
H^{\prime}=-\sum_{i=1}^{S} p_{i} \ln p_{i}
$$

where $S$ stands for total species richness and $p i$ for the relative frequency of the $i$-th species (Magurran, 2004). To estimate the total potential size of the flora we used the Chao 2 algorithm $\left(S_{\text {Chao } 2}\right.$; Chao, 1984, 1987), which is based on incidence data (presence/absence of species in sampling plots):

$$
S_{\text {Chao } 2}=S_{\text {obs }}+\frac{\mathrm{Q}_{1}^{2}}{2 \mathrm{Q}_{2}},
$$

where $S_{o b s}$ is the observed number of species, $Q_{1}$ is the number of species occurring in just one plot and $Q_{2}$ is the number of species occurring in exactly two plots. These calculations were performed with EstimateS ver. 9.1.0 (Colwell, 2013).

We calculated the frequency, density, cover and basal area for each species and the total of each of these variables by plot, by geomorphological unit, and for the entire set of oak forests plots. With the relative values of basal area, density and frequency we calculated the importance value index (IVI) of each species both for the entire oak forests and by geomorphological units separately. As the data for structural variables did not meet the assumptions of parametric tests, we used the Kruskal-Wallis test for all the comparisons. When this test was significant, we performed Kruskal-Wallis multiple comparisons as a post hoc test $(\alpha=0.05)$. We conducted all statistical analyses with the software $\mathrm{R}$ version 3.0.2. ( $\mathrm{R}$ Development Core Team, 2010).

\section{Results}

General description of the oak forest in the TNP. We collected 1,321 specimens of terrestrial vascular plants, almost all of them $(96.7 \%)$ within the sampling plots. We could identify to species level a large fraction of these specimens (83.9 $\%$ ), while $6.5 \%$ and $4.7 \%$ could be only determined to genus and family levels, respectively. The remaining specimens $(4.9 \%)$ could not be determined to any level. Appendix 2 is the checklist of taxa identified at least to genus level, including 88 families, 208 genera and 341 species. Among the latter, $85.6 \%$ were angiosperms, $12.1 \%$ were ferns and allies, and $2.3 \%$ were gymnosperms. Asteraceae was the richest family, which with 57 species and 29 genera, largely

Table 1. Number of species and genera of vascular plant families with more than five species, present in the oak forests from the El Tepozteco National Park, Mexico.

\begin{tabular}{lcc}
\hline Family & No. of species & No. of genera \\
\hline Asteraceae & 57 & 31 \\
Fabaceae & 28 & 18 \\
Poaceae & 19 & 11 \\
Pteridaceae & 17 & 9 \\
Lamiaceae & 17 & 7 \\
Solanaceae & 13 & 4 \\
Polypodiaceae & 11 & 4 \\
Rubiaceae & 9 & 7 \\
Orchidaceae & 7 & 6 \\
Asparagaceae & 7 & 3 \\
Pinaceae & 7 & 1 \\
Euphorbiaceae & 6 & 2 \\
Fagaceae & 6 & 1 \\
\hline
\end{tabular}


Table 2. Vascular plant genera with more than five species in the oak forests from the El Tepozteco National Park, Mexico.

\begin{tabular}{lc}
\hline Genus & No. of species \\
\hline Salvia & 10 \\
Pinus & 7 \\
Polypodium & 7 \\
Roldana & 7 \\
Ageratina & 6 \\
Cestrum & 6 \\
Desmodium & 6 \\
Quercus & 6 \\
Stevia & 6 \\
\hline
\end{tabular}

exceeded Fabaceae, the family that ranked second in species richness (Table 1). With 11 species, the richest genus was Salvia, followed by Cheilanthes, which was represented by eight species (Table 2).

We recorded a total of 324 species in the sampling plots. Mean richness per $100-\mathrm{m}^{2}$ plot ( \pm 1 S.E.) was $25 \pm 1.13$ species (range: 6-43 species). $H^{\prime}$ for the entire oak forest (i.e., all plots in all units combined) was 5.327, a value equivalent to 205.89 effective (equally frequent) species. In turn, the total size of the flora according to Chao 2 estimator was 446.19 species.

The understory species with the highest cover area was Salvia polystachia, followed by S. mexicana and Verbesina virgata. In turn, the most frequent understory species was Clematis dioica, recorded in $42 \%$ of the plots, followed closely by $V$. virgata, Bomarea edulis and $S$. polystachia (occurring in 38,37 and $37 \%$ of the plots, respectively).

We tallied 492 individuals forming part of the canopy (i.e., $\mathrm{DBH} \geq 2.5 \mathrm{~cm}$ ), distributed among 52 species. More than a quarter of them were multi-stemmed, thus in total we measured 818 stems with a DBH $>2.5 \mathrm{~cm}$. Over $80 \%$ of the basal area and $68 \%$ of the canopy cover were accounted for by only 129 very large trees (i.e., DBH $\geq 20 \mathrm{~cm}$ ). Conversely, density concentrated among the individuals in lower diametric categories, since more than half of the stems were between 2.5 and $10 \mathrm{~cm}$ in $\mathrm{DBH}$.

Comparison between geomorphological units. Mean species richness per plot varied significantly between geomorphological units $(P<0.0001)$. The forest from Chichinautzin had the highest mean $( \pm$ S.E. $)$ richness per plot: $33.5 \pm$ 1.38 species, and this figure was significantly higher than most other units, except for Suchiooc $(24.4 \pm 1.82)$ and the El Tepozteco Range (27.1 \pm 2.33$)$. The opposite extreme was observed for Oclayuca, whose mean richness of only $12.0 \pm$ 1.67 species per plot was significantly lower than most units except for forests in upper and lower Otates $(21.4 \pm 2.59$ and $19.4 \pm 1.78$, respectively).

Total richness in the geomorphological units, both observed and estimated, showed a similar pattern (Figure 2). The Oclayuca forest was the least rich (60 species), in strong contrast to Chichinautzin, the richest among the forests occurring on lava substrate, with a total of 114 species. Nonetheless, the forest of the El Tepozteco Range was even richer (149 species). The differences between observed and effective numbers of species according to $H$ ' are illustrative about community evenness in the different forests. For example, though richer, the Chichinautzin forest was less even than the Oclayuca forest.

Both frequency and cover of understory species varied remarkably between geomorphological units (Figure 3). Several very frequent species in the Chichinautzin forest like Sedum oxypetalum and Echeveria gibbiflora were absent from other units. In contrast, other species like Salvia mexicana were common across several units. Generally, there were only one or two dominant species in each unit

Table 3. Structural variables assessed in oak forests occurring in six geomorphological units of the El Tepozteco National Park. Values represent means \pm 1 S.E. Values between parentheses indicate the ranges for those variables. Values are for plants with $\mathrm{DBH} \geq 2.5 \mathrm{~cm}$, which correspond to the stratum named canopy in this study.

\begin{tabular}{|c|c|c|c|c|}
\hline Geomorphological unit & $\begin{array}{c}\text { Basal area } \\
\left(\mathrm{m}^{2} \mathbf{h a}^{-1}\right)\end{array}$ & $\begin{array}{c}\text { Cover } \\
\left(\mathbf{m}^{2} \mathbf{h a}^{-1}\right)\end{array}$ & $\begin{array}{l}\text { Height } \\
\text { (m) }\end{array}$ & $\begin{array}{l}\text { Stem density } \\
\text { (ind. ha-1) }\end{array}$ \\
\hline Chichinautzin & $\begin{array}{l}19.6 \pm 2.8 \\
(3.4-29.0)\end{array}$ & $\begin{array}{l}10,424 \pm 1,830 \\
(1,743-18,577)\end{array}$ & $\begin{array}{r}9.0 \pm 0.7 \\
(5.5-11.8)\end{array}$ & $\begin{array}{c}610.0 \pm 99.4 \\
(100-1100)\end{array}$ \\
\hline Suchiooc & $\begin{array}{c}42.0 \pm 4.3 \\
(20.3-66.5)\end{array}$ & $\begin{array}{r}20,919 \pm 2,315 \\
(9,889-29,957)\end{array}$ & $\begin{array}{c}14.4 \pm 1.2 \\
(11.0-24.0)\end{array}$ & $\begin{array}{c}1,040.0 \pm 172.0 \\
\quad(400-1,900)\end{array}$ \\
\hline Upper Otates & $\begin{array}{r}46.4 \pm 10.6 \\
(10.3-120.9)\end{array}$ & $\begin{array}{r}21,526 \pm 3,995 \\
(6,440-42,313)\end{array}$ & $\begin{array}{l}16.7 \pm 2.1 \\
(7.2-25.5)\end{array}$ & $\begin{array}{l}940.0 \pm 131.8 \\
(300-1,900)\end{array}$ \\
\hline Lower Otates & $\begin{array}{l}42.3 \pm 7.9 \\
(0.2-81.3)\end{array}$ & $\begin{array}{c}31,341 \pm 6,135 \\
(577-65,475)\end{array}$ & $\begin{array}{l}15.2 \pm 2.0 \\
(2.9-23.2)\end{array}$ & $\begin{array}{l}900.0 \pm 182.0 \\
(100-2,200)\end{array}$ \\
\hline Oclayuca & $\begin{array}{l}60.5 \pm 15.4 \\
(6.5-145.9)\end{array}$ & $\begin{array}{l}26,041 \pm 3,868 \\
(8,536-44,260)\end{array}$ & $\begin{array}{l}22.8 \pm 4.0 \\
(11.5-55.0)\end{array}$ & $\begin{array}{l}990.0 \pm 172.8 \\
(300-2,000)\end{array}$ \\
\hline El Tepozteco Range & $\begin{array}{l}32.7 \pm 6.2 \\
(0.5-56.1)\end{array}$ & $\begin{array}{c}22,028 \pm 2,903 \\
(2,768-31,671)\end{array}$ & $\begin{array}{l}13.3 \pm 1.3 \\
(7.6-20.0)\end{array}$ & $\begin{array}{l}810.0 \pm 79.5 \\
(400-1,100)\end{array}$ \\
\hline
\end{tabular}



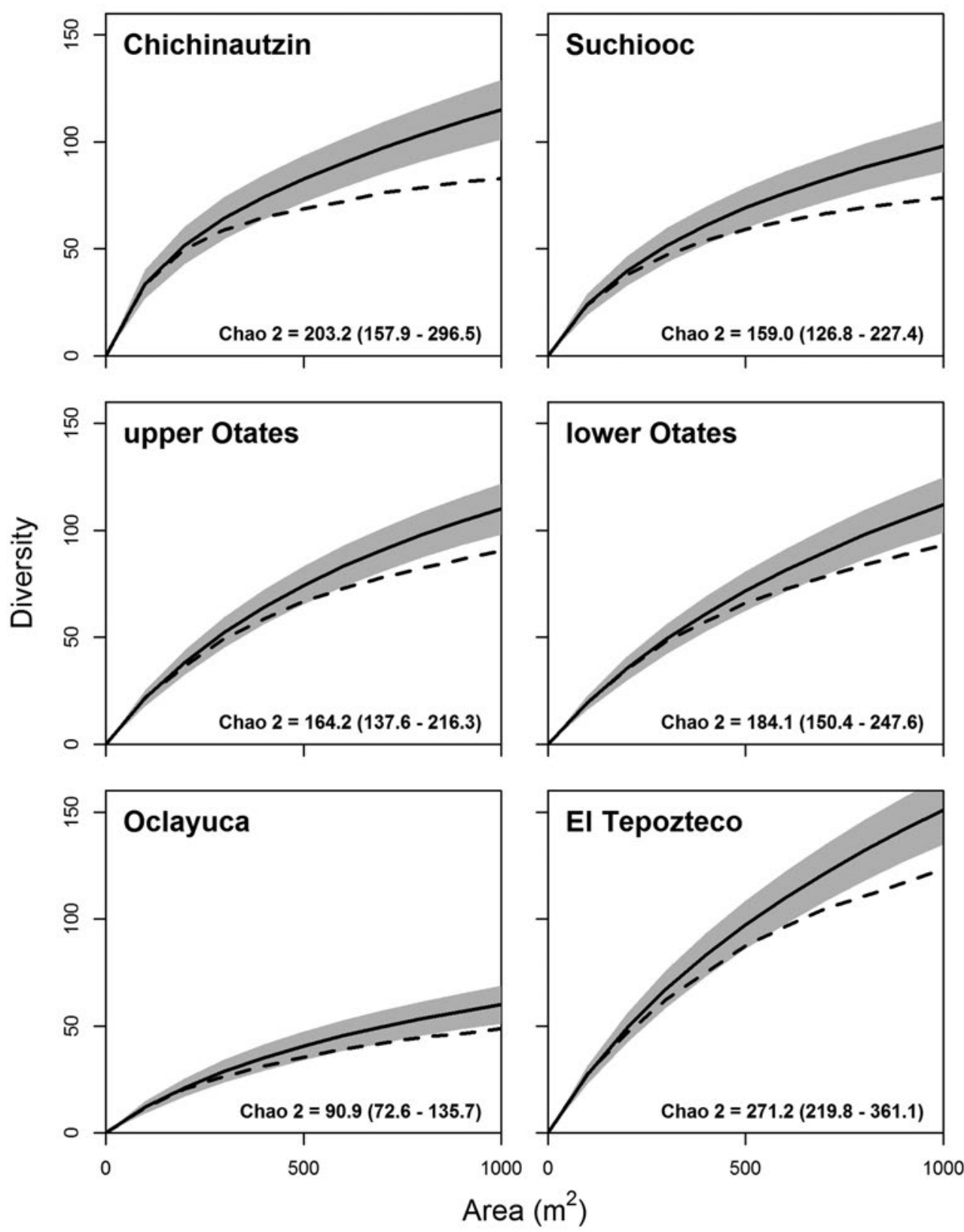

Figure 2. Smoothed diversity accumulation curves for species richness according to the Mao Tau procedure (continuous line; gray area depicts $95 \%$ confidence intervals) and for the effective number of species of Shannon Index (dashed line) for each geomorphological unit.

but many rare species with similar IVIs. The only exception to this pattern was Oclayuca, where four species had high IVIs. The two species having the highest IVIs in the El Tepozteco Range and in the lower Otates forests, Rumfordia floribunda and Paspalum squamulatum, respectively, had large cover values in very few plots; on the contrary, other species like Bomarea edulis and Asplenium monanthes were very frequent in some units but had very low cover due to their small size.

We found considerable differences in the structural variables between units (Table 3), but these were not always significant. In Chichinautzin we recorded the lowest values for all variables. Conversely, the forest in Oclayuca had the highest basal area and height, the lower Otates forest had the maximum canopy cover, and the Suchiooc forest the highest density. Differences in basal area were not significant $(P=0.105)$, but mean height values differed significantly between Chichinautzin and upper Otates and Oclayuca $(P$ $=0.0007)$. Cover also differed significantly between units $(P=0.015)$. Although having half or less the cover value of any other unit, Chichinautzin only differed significantly from lower Otates and Oclayuca, according to the Tukey test. In turn, despite a difference of 430 individuals $\mathrm{ha}^{-1}$ between the extreme density values of the different oak for- 


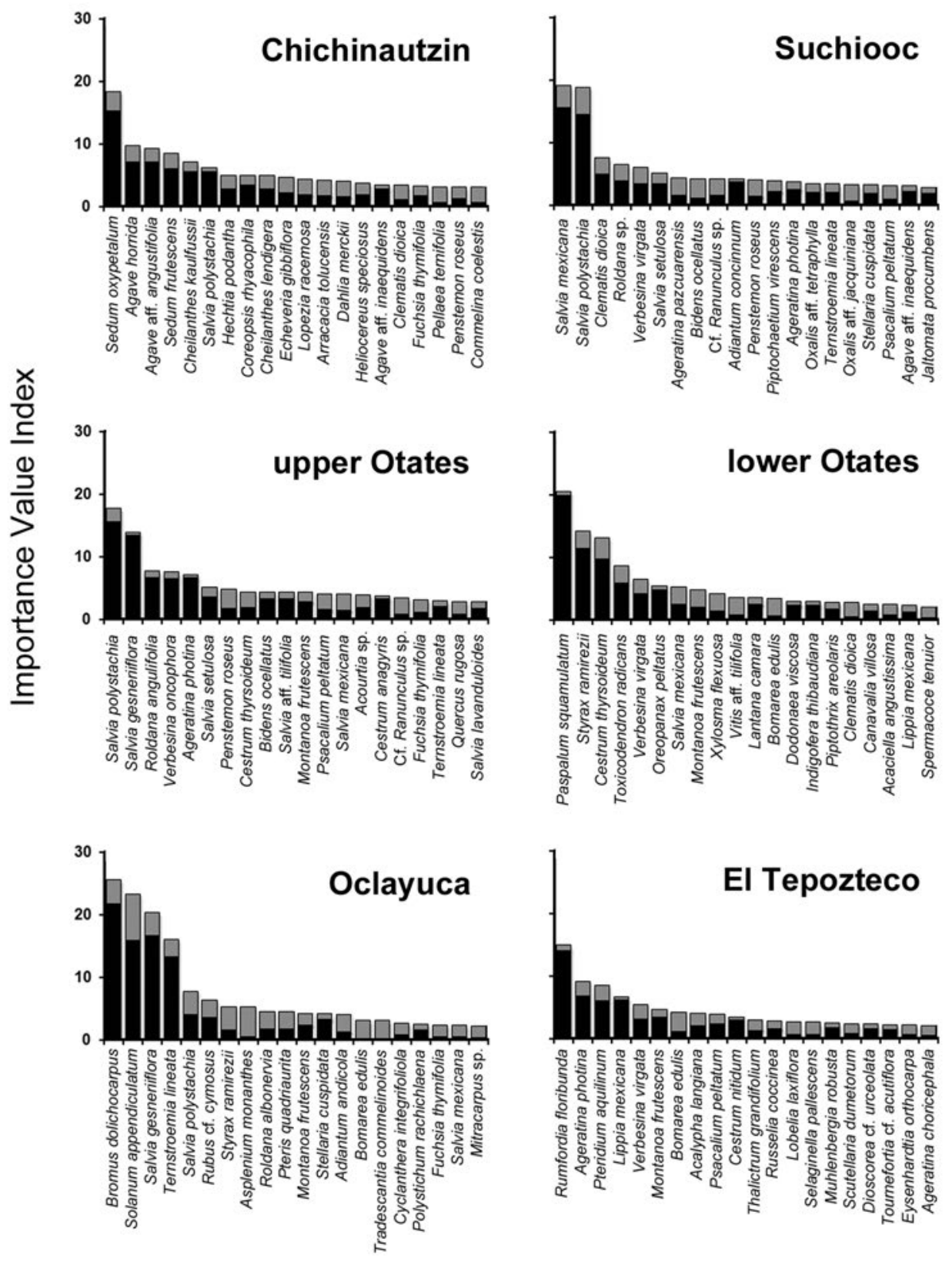

Figure 3. Importance value indices (IVI) of the 20 most dominant plant species in the oak forest understory in the different geomorphological units of the El Tepozteco National Park. For each species, the absolute contributions of their cover (black bars) and frequency values (gray bars) are distinguished. Note: Cf. Ranunculus sp., reported for Suchiooc and upper Otates units, is a morphospecies with uncertain generic identification.

ests (Table 3 ), differences in density were not significant $(P=0.479)$.

In all units, most individuals had low DBH values, so the frequency distributions of diameter classes always had the common shape of an inverted J (Figure 4); however, in some units this pattern was more evident than in others. For instance, both in Oclayuca and in lower Otates over $70 \%$ of the stems had a DBH $\leq 10 \mathrm{~cm}$, while in the El Tepozteco Range and Chichinautzin less than half of them were in this size class. The Chichinautzin forest also was unique in that
$30 \%$ of the stems had a DBH between 10 and $20 \mathrm{~cm}$, and almost $20 \%$ between 20 and $30 \mathrm{~cm}$. In contrast, Oclayuca and lower Otates (the units with the largest proportion of stems in the lowest diameter class) were the only sites where we recorded stems with a DBH $>1 \mathrm{~m}$.

The IVIs of canopy species recorded in more than one geomorphological unit were highly variable among them (Figure 5). Quercus rugosa was dominant in Chichinautzin, Suchiooc and upper Otates. In Chichinautzin, this species' IVI was three times higher than the one for Arbutus xala- 

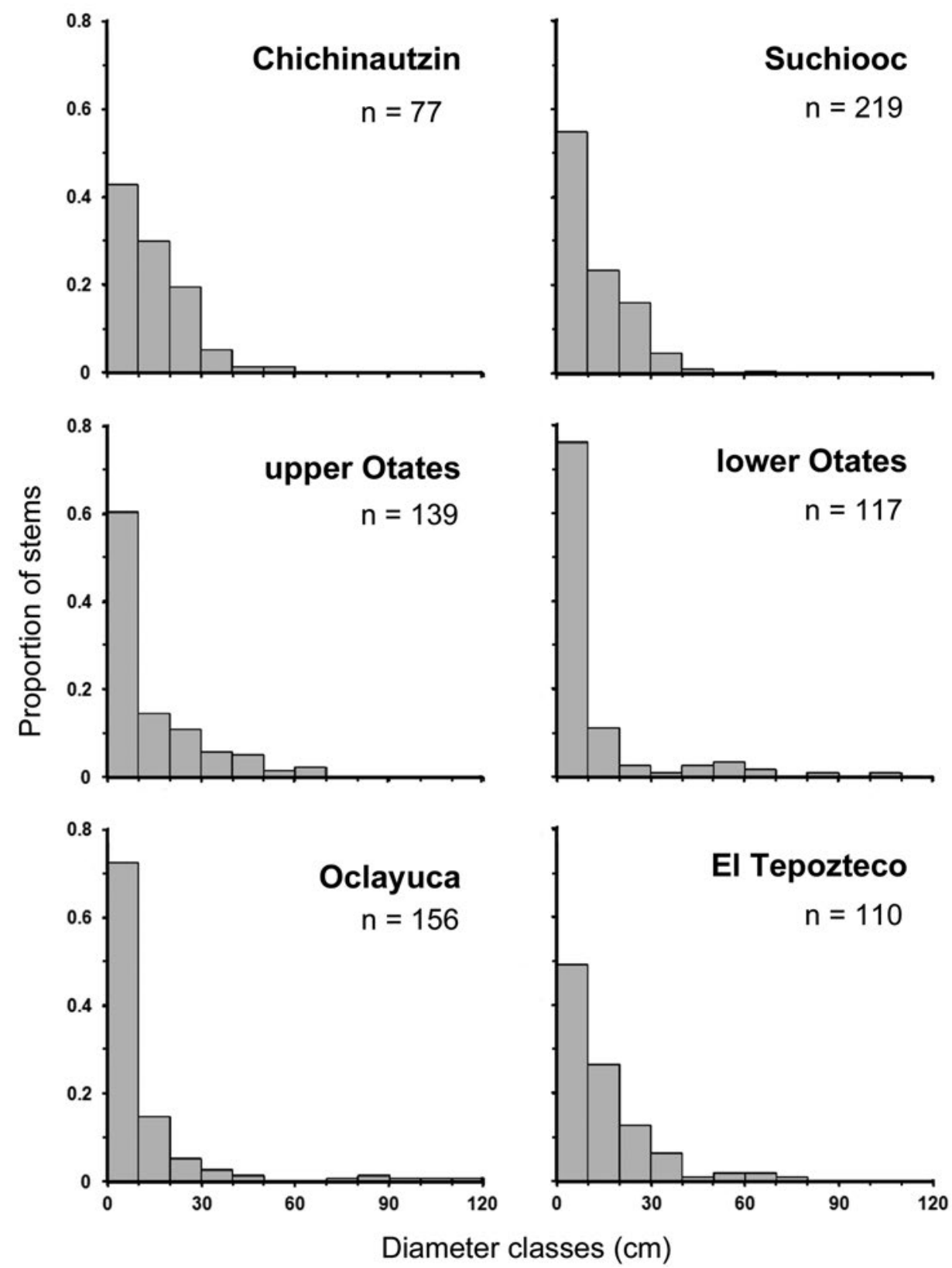

Figure 4. Frequency distribution of stem diameter classes in the oak forests occurring on different geomorphological units present in the El Tepozteco National Park.

pensis, the second-most dominant species. While Q. rugosa occurred in nine of ten plots in Chichinautzin and Suchiooc, half of the canopy species in those units were recorded in a single plot only. In Suchiooc, $Q$. rugosa contributed with ca. $60 \%$ of the total density and $70 \%$ of the total basal area, while its IVI was five times higher than that for Ternstroemia lineata, the second-most dominant species in that unit. Contrastingly, dominance of this oak species was less marked in upper Otates, where Quercus laurina, Baccharis conferta and Arbutus xalapensis followed it closely in terms of IVI. Interestingly, a different structural variable made the largest contribution to the IVIs of each of these species: ba- sal area for $Q$. laurina, density for $B$. conferta, and frequency for A. xalapensis.

Both in lower Otates and in Oclayuca, Styrax ramirezii was dominant, albeit not as markedly as Quercus rugosa in the units discussed above. The IVI of $S$. ramirezii was very similar to those of $Q$. castanea in lower Otates and of $Q$. laurina in Oclayuca. Notably, in these two units dominance of $S$. ramirezii was accounted for by its density, since it had less basal area than five and three species in lower Otates and Oclayuca, respectively.

The forest at the El Tepozteco Range, which had the highest canopy richness ( 25 species) and diversity, had the 

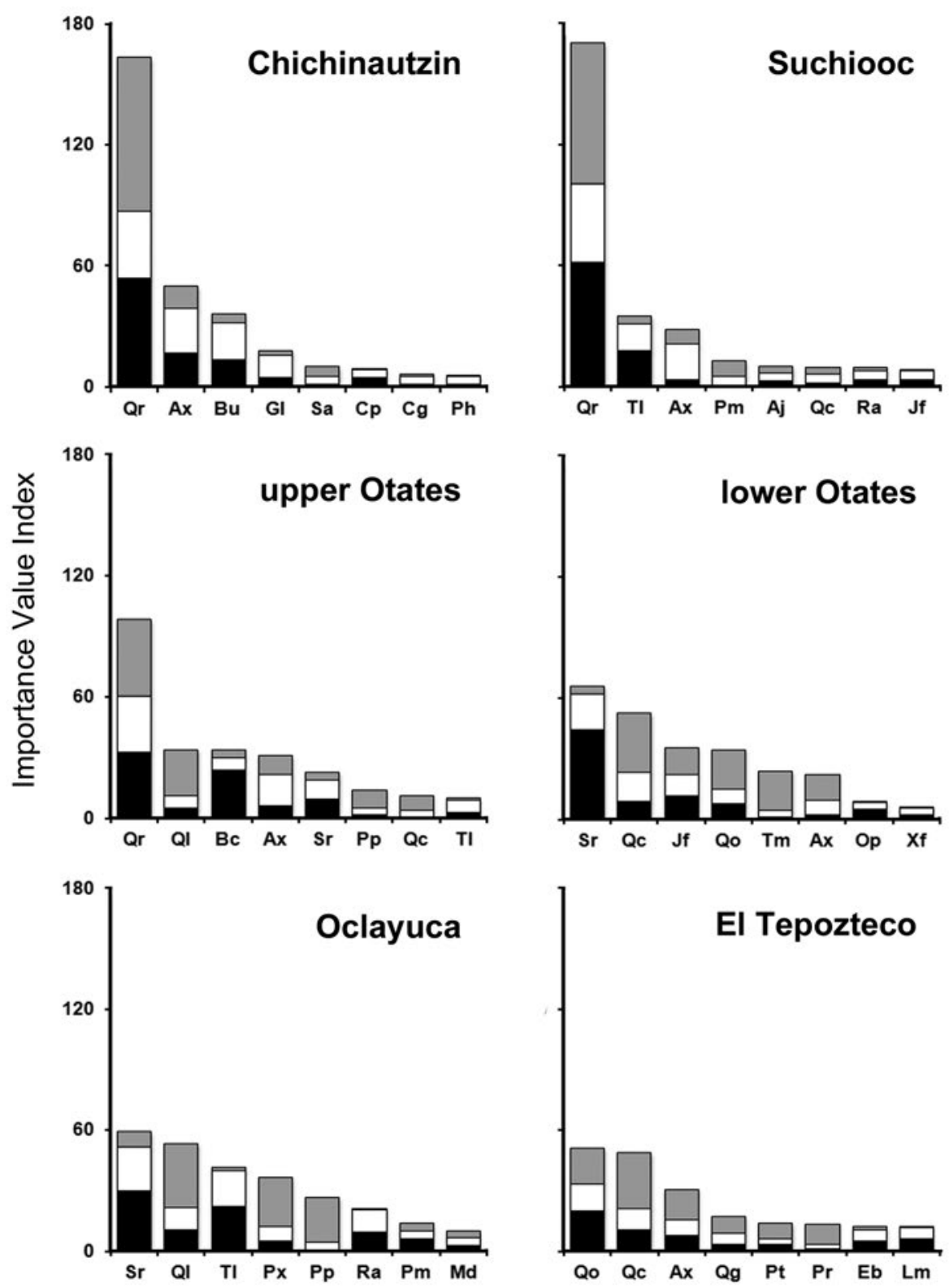

Figure 5. Importance value indices (IVI) of the eight most dominant canopy species of the oak forests occurring in different geomorphological units of the El Tepozteco National Park. For each species, its absolute contributions in terms of density (black bars), frequency (white bars) and basal area (gray bars) are distinguished. $\mathrm{Aj}=$ Alnus jorullensis; $\mathrm{Ax}=$ Arbutus xalapensis; $\mathrm{Bc}=$ Baccharis conferta $; \mathrm{Bu}$ $=$ Buddleja cordata $; \mathrm{Cg}=$ Comarostaphylis glaucescens $; \mathrm{Cp}=$ Celastrus pringlei $; \mathrm{Eb}=$ Erythrina breviflora $; \mathrm{Gl}=$ Garrya laurifolia $; \mathrm{Jf}=$ Juniperus flaccida $; \mathrm{Lm}=$ Lippia mexicana $; \mathrm{Md}=$ Meliosma dentata $; \mathrm{Op}=$ Oreopanax peltatus $; \mathrm{Ph}=$ Pinus hartwegii $; \mathrm{Pm}=$ Pinus montezumae $; \mathrm{Pp}=$ Pinus pseudostrobus; $\mathrm{Pr}=$ Pinus pringlei $; \mathrm{Pt}=$ Pinus teocote $; \mathrm{Px}=$ Pinus maximinoi $;$ Qc $=$ Quercus castanea $; \mathrm{Qg}=$ Quercus glaucoides $; \mathrm{Ql}=$ Quercus laurina $; \mathrm{Qo}=$ Quercus obtusata $; \mathrm{Qr}=$ Quercus rugosa $; \mathrm{Ra}=$ Roldana albonervia $; \mathrm{Sa}=\mathrm{Saurauia} \mathrm{sp} . ; \mathrm{Sr}=$ Styrax ramirezii $; \mathrm{Tl}=$ Ternstroemia lineata $; \mathrm{Tm}=$ Trophis mexicana $; \mathrm{Xf}=$ Xylosma flexuosa .

smallest differences in IVI among its dominant species. The two most dominant oaks, Quercus castanea and Q. obtusata, had almost identical IVIs; the former due to its highest basal area, the latter due to the highest density and frequency. In fact, with the exception of $Q$. obtusata, all other species appeared in less than half of the plots. In the canopy of the forest in the El Tepozteco Range, Q. glaucoides and $Q$. rugosa were also present, which means that this unit had the highest richness of oak species overall (four out of six recorded in this study).

\section{Discussion}

Overall analysis of oak forest richness and composition in the TNP. To our knowledge, no complete and reliable inventory of the flora of TNP was available until the present study 

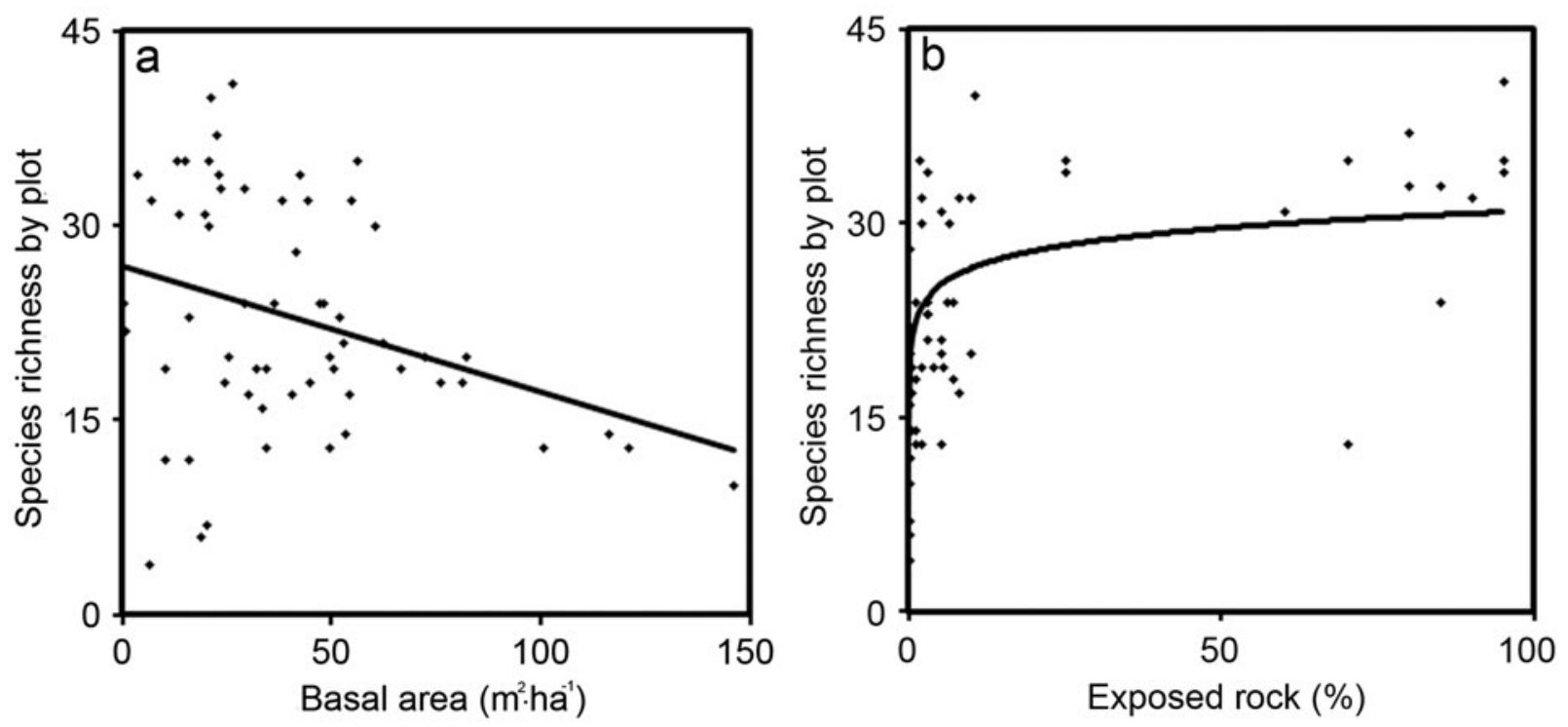

Figure 6. (A) Linear regression $(y=-0.0974 x+26.936)$ of species richness on basal area, $R^{2}=0.10, P=0.002$. (B) Nonlinear regression $(y=1.9239 \ln x+22.104)$ of species richness on percentage of exposed rock by plot, $R^{2}=0.44, P<0.001$.

was conducted. Any existing botanical information on the park until date has been inconsistent and incomplete. The TNP draft management plan reports the presence of 1,119 species of vascular plants; nonetheless, this checklist seems to be only based on documental research since there is no evidence of any fieldwork supporting it. In turn, the Program for a Land Use Plan (Plan para el Ordenamiento Ecológico y Territorial) for the Tepoztlán Municipio (Municipio being an administrative unit roughly equivalent to a county in other countries; Anonymous, 2006) includes a list of 566 vascular plant species. This figure undoubtedly underestimates the plant richness of the park, considering that the list does not include common and abundant species reported in this paper, like Quercus rugosa, which was the dominant species in most of the oak forests studied by us.

Flores-Castorena and Martínez-Alvarado (2010) conducted a floristic study of the vascular plants of the entire protected area known as the Chichinautzin Biological Corridor (of which TNP is a part), and found 1,265 species. However, it is also evident that their checklist is incomplete, since it lacks around one fourth of the species that we report, some of them also being frequent and abundant in the TNP oak forests, such as Ageratina photina, Bidens ocellatus, Psacalium peltatum, and Toxicodendron radicans. Moreover, other floristic studies conducted in the Corridor, though covering smaller areas, have reported large numbers of species. For example, Cerros-Tlatilpa and Espejo-Serna (1998) conducted a floristic survey on two hills of the Tlayacapan Municipio, adjacent to Tepoztlán, and reported 368 species of spermatophytes. Similarly, Hernández-Cárdenas et al. (2014) studied the flora of the Tepecapa ravine, also in Tlayacapan Municipio, and found 434 species of vascular plants. These figures strongly suggest that there is still a great deal of relevant basic floristic knowledge to be gained from the study of the vascular flora of TNP and the entire Chichinautzin Biological Corridor, in particular of dicots, as monocots have been studied more thoroughly (Pulido-Esparza et al., 2009). The study of the bryophytes of the park is also urgent, as there does not seem to be any study about this group in spite of its recognized importance in several other Neotropical oak forests (Holz, 2006).

Considering that the goal of our study was not to conduct an exhaustive floristic exploration of the park's oak forests, the magnitude of the recorded flora (341 species, including the 17 species recorded outside the plots) suggests that the oak forests host a large proportion of TNP's plant diversity, and that this concerns a natural protected area of great biological richness. This conclusion is further supported by the outcomes of the comparison of our results with available information from elsewhere, for example, from the Lagunas de Zempoala National Park (also embedded within the Chichinautzin Biological Corridor) for which there is a report of 359 species of vascular plants (Bonilla-Barbosa and Viana-Lases, 1997). In other Mexican temperate forests, species richness varies within the same order of magnitude. For instance, in the Abies religiosa forests located in the core zone of the Monarch Butterfly Biosphere Reserve there are 423 species of vascular plants (Cornejo-Tenorio et al., 2003), whereas for the oak forests of the Zapalinamé Range (Coahuila State, N Mexico), only 239 species have been reported (Encina-Domínguez et al., 2007). Further south, in a study of the oak forests of the Talamanca Cordillera, Costa Rica, Kappelle et al. (1995b) reported 431 species of terrestrial vascular plants. Though in many of these examples the respective flora is certainly richer than the one we report here, it must be taken into account that all of them were truly floristic studies based on botanical expeditions during at least one annual cycle, and supplemented with information from 
literature and herbarium specimens. Therefore, future floristic research in the TNP is very likely to reveal the existence of an even richer flora than that reported in this paper.

This conclusion is also based on the limited scope of our study, due to the decision to solely include terrestrial vascular plants present in the oak forests. As mentioned in the description of the study site, the TNP encompasses other well-represented vegetation types, such as pine forest, fir forest, subalpine grassland and seasonally dry tropical forest, each of them having a sizeable array of species not occurring in the park's oak forests. As an example, among the 13 natural plant communities studied by Velázquez and Cleef (1993) along the slopes of the Tláloc and Pelado volcanoes, nearby and similar to the volcanoes of the TNP, six are dominated by species not found by us in this study. Moreover, the exclusion of epiphytes from our analysis also produces an underestimation of the total size of the flora, as these plants may represent up to one third of the total number of species in some tropical mountain forests (Gentry and Dodson, 1987), and are of particular importance in some highland oak forests in the Neotropics (Wolf and Flamenco-S., 2006).

The proportions of species in each supra-familiar taxon are similar to those recorded for other Mexican temperate forests (e.g., Ramírez-Marcial et al., 1998; Medina-García et al., 2000), although the proportion of ferns and allies was higher than in the Monarch Butterfly Biosphere Reserve (Cornejo-Tenorio et al., 2003). The most speciose family was Asteraceae, as in most temperate highland forests in the country (e.g., Luna-Vega et al., 1994; Cerros-Tlatilpa and Espejo-Serna, 1998; Ramírez-Marcial et al., 1998; Cornejo-Tenorio et al. 2003; Martínez-Cruz and Téllez-Valdés, 2004), as well as in other countries (e.g., in Colombia; $\mathrm{Pu}-$ lido et al., 2006). In the Costa Rican mountain oak forests studied by Kappelle et al. (1995a), Asteraceae ranked third by number of species. In turn, Fabaceae and Poaceae, the second and third most diverse families in this study, also have similar positions in other Mexican temperate forests (Cerros-Tlatilpa and Espejo-Serna, 1998; Medina-García et al., 2000). Similarly, some of the most diverse families in our study, such as Lamiaceae, Solanaceae, Polypodiaceae and Orchidaceae, and the most diverse genera, such as Salvia, Ageratina, Roldana, Pinus, Polypodium and Stevia, bear the same status in several other Mexican temperate forests (e.g., Cerros-Tlatilpa and Espejo-Serna, 1998; MedinaGarcía et al., 2000; Cornejo-Tenorio et al. 2003).

The relatively small number of monocot species that we found is noteworthy, as the Chichinautzin Biological Corridor is known for a high diversity of orchids, bromeliads and grasses (Cerros-Tlatilpa and Espejo-Serna, 1998; Pulido-Esparza et al., 2009). This paradox may be related again to the exclusion of epiphytes from our study, since a large number of bromeliads and orchids possess such growth habit. Ancillary observations during fieldwork indi- cate that epiphytes are especially abundant in oak forests of Chichinautzin and El Tepozteco Range, and thus they likely represent an important component of the flora in those units. Furthermore, most of the monocots of the Chichinautzin Biological Corridor occur at higher elevations, e.g., in conifer forests (Pulido-Esparza et al., 2009).

The TNP borders to the north the upper reaches of the Basin of Mexico (an endorrheic basin where Mexico City is located), which explains the large floristic similarity with that region. The floras of these two geographical regions share characteristic components of Mesoamerican mountains, including genera such as Fuchsia, Geranium, Lamourouxia, Rubus and Thalictrum. In addition, several species typical of the very humid mountains of Mexico occur, like Celastrus pringlei, Clethra mexicana, Fraxinus uhdei, Meliosma dentata, Oreopanax peltatus and Symplocos citrea. However, a remarkable difference is that the oak forest flora of the TNP comprises families characteristic of the hot lowland regions of the country that have not been found in the Basin of Mexico, such as Annonaceae and Flacourtiaceae (the latter being currently included in Salicaceae; Rzedowski, 2005). The relatively high abundance of tropical families was to be expected, given the location of the TNP along the southern slopes of the Trans-Mexican Neo-Volcanic Belt, and therefore this region has a transitional character between this physiographic unit and the lowlands of the Balsas River Basin.

Comparison of oak forests diversity between geomorphological units. Our results showed a large variation in mean species richness per plot between geomorphological units, as well as in the observed and estimated richness for the whole units (see Figure 2). Interestingly, the largest mean species richness per plot was recorded in the youngest lava field (Chichinautzin), whereas the oldest lava field (Oclayuca) had the smallest. In contrast, the lava fields with the largest effective number of species (i.e., equally frequent species) were those of intermediate ages (upper and lower Otates). Such large differences in species richness and community diversity between sites created by volcanic activity at different periods strongly suggest that the differences are related to a primary successional process and the associated changes in environmental conditions (Cano-Santana and Meave, 1996; Walker and del Moral, 2003). Though some studies have found larger plant richness in old lava fields than in young ones (Aplet et al., 1998), most of them report a steady increase in plant richness during the first 300 years of succession, followed by a decrease (Kitayama et al., 1995). The initial increase in richness may be explained as a result of rapid colonization by pioneer species, which creates environmental conditions that facilitate subsequent, and usually much slower, community enrichment. Nonetheless, after this initial enrichment other processes that lowered species richness must have taken place. For example, it is plausible that with successional development the microenvironmental 
heterogeneity of the site decreased. Pahoehoe lava fields, like those occurring in TNP, are characterized by a high microtopographic heterogeneity with numerous crevices, cavities and walls, offering a variety of microhabitats that allow the coexistence of species with different environmental requirements (Santibáñez-Andrade et al., 2009). This is a widely-accepted explanation for the high plant richness on the lava fields of central Mexico (Rzedowski, 1954), which is in agreement with broad generalizations for highly heterogeneous habitats (Rosenzweig, 1995). As succession proceeded, weathering, organic matter accumulation, and other soil forming processes created a more homogeneous environment until the whole terrain was covered with a deep soil layer (Cano-Santana and Meave, 1996; Walker and del Moral, 2003), as in the Oclayuca lava field. These changes in environmental heterogeneity associated with the successional process could also help explain the differences in community diversity. Although the Shannon effective number of species peaked in the lower and upper Otates forests, of intermediate age, we must keep in mind that these units are a complex of different lava fields. Apart from the Otates units, the effective number of species also decreased with increasing unit age, being highest in the Chichinautzin forest and lowest in Oclayuca.

Environmental heterogeneity in the youngest lava field is particularly relevant at the microscale level, which implies that it is associated with a large variety of habitats mainly for small plants, such as herbs. This explains why the Chichinautzin forest had the highest mean richness per plot while having the poorest canopy. A high contribution of the herbaceous component for total richness has been reported for other plant communities occurring on top of old lava fields (e.g., Castillo-Campos et al., 2007). However, from our results it is also evident that other geomorphological units unrelated to lava fields can be very heterogeneous and biologically diverse as well, as demonstrated in the El Tepozteco Range. In this unit, microscale heterogeneity fosters local diversity and understory richness, as in Chichinautzin. In El Tepozteco, however, the presence of numerous ravines, cliffs, and the overall complex topography, creates between-plot heterogeneity. This analysis of heterogeneity across spatial scales explains why, although Chichinautzin had the richest plots on average, the total diversity of the geomorphological unit was largest at El Tepozteco. Likewise, the interplay of environmental heterogeneity at different spatial scales could account for the higher evenness of the oak forest of El Tepozteco, which had the largest number of equally frequent species.

Another possible explanation for the lower species richness in sites with older volcanic substrates is that, with deeper soils and fewer nutrient limitations, some strongly competitive species are more likely to displace many other species. According to community assembly models based on stochastic equilibrium processes, nutrient limitation may result in a decrease of the speed of competitive displacement (Huston, 1994). Basal area is a good estimator of community biomass and therefore of ecosystem productivity. The forest that occurs on the oldest lava field had the smallest species richness and the highest basal area, in agreement with the sometimes-reported negative relation between productivity and species richness (Huston, 1980; Waide et al., 1999).

In the absence of precise information, the percentage of exposed rock in a plot can be used as a proxy for substrate heterogeneity for plants. To gain a better insight about the relationships between richness and productivity, and between richness and environmental heterogeneity, we performed regression analyses of the number of species on basal area and on percentage of exposed rock. Both regressions were significant, i.e., the number of species in the plots significantly decreased with increasing basal area, whilst it was positively related to the percentage of exposed rock (Figure 6). However, basal area only explained a small fraction of the variance in species richness ( $\mathrm{ca} .10 \%)$, while the percentage of exposed rock explained $44 \%$ of such variance. In fact, the richness-basal area relationship can be described as triangular, as richness was considerably more variable among plots with low basal area, whereas high basal area was always associated with low richness (Figure 6A). In plots with low basal area, low richness can also be due to anthropogenic disturbance; in the absence of this factor, plots could potentially contain more species. Further, intrinsic mechanisms that limit species richness may also operate in plots with high basal area, independently of extrinsic factors like anthropogenic disturbance. For example, large trees may cast deep shade, thus creating a light-limited environment at ground level; this would in turn constrain the growth potential of herbaceous plants, which is, as discussed earlier, the vegetation component with the largest contribution to species richness in this forest (Mooney and Ehleringer, 1997). In addition to light limitations, plots with larger trees tend to have a higher litter accumulation, which may hinder plant recruitment (Facelli and Pickett, 1991; Mejía-Domínguez et al. 2011). In our study, the species with the largest contributions to total basal area in the forests were oaks and pines, whose litter is particularly difficult to decompose due to high contents of tannins and terpenes, respectively (Schulze et al., 2002). Because of their slow decomposition, the litter of these trees (especially of pines) tends to accumulate in the soil. The largest structural contribution of pines was observed in the Oclayuca forest, which could partially explain the low richness of its understory community.

\section{Conclusions}

Oak forests of the TNP represent a structurally highly variable plant community that hosts a large diversity of plants. The spatial distribution of this diversity is highly uneven as 
a result of the strong environmental heterogeneity occurring in the region, which in turn is linked to long-term successional processes derived from past volcanic activity. In recognition of such abiotic and biotic heterogeneity, which is probably not limited to the plant component of the ecosystem alone, but also true for other biological groups, the array of volcanic substrates and the associated variable oak forest offer an adequate framework for planning conservation and restoration activities that are urgently needed to maintain oak forest health in this important natural protected area.

\section{Acknowledgments}

The Mexican National Commission for Natural Protected Areas (CONANP) kindly granted the authorization to conduct this study in the TNP. We are indebted to all people who assisted during fieldwork, particularly Iván Ponomarev, Elir Negri, Mauricio Rea, Omar Velázquez, Rodrigo Hernández-Cárdenas, Eduardo A. Pérez-García, Marco A. RomeroRomero, León F. Chávez, and Rafael Martínez. This paper greatly benefited from the comments of Arturo Sánchez González and Marteen Kapelle on an earlier version.

\section{Literature cited}

Anonymous. 2006. Programa de Ordenamiento Ecológico del Territorio del Municipio de Tepoztlán, Morelos. Memoria técnica. Honorable Ayuntamiento de Tepoztlán and Universidad Autónoma del Estado de Morelos, Tepoztlán.

APG III. 2009. An update of the Angiosperm Phylogeny Group classification for the orders and families of flowering plants: APG III. Botanical Journal of the Linnean Society 161:105-121.

Aplet G.H., Hughes R.F. and Vitousek P.M. 1998. Ecosystem development on Hawaiian lava flows: biomass and species composition. Journal of Vegetation Science 9:17-26.

Ávila-Bravo V. 1998. Cartografía geológica y estratigrafía del grupo Chichinautzin, en el área de Tepoztlán, Morelos. B.Sc. Thesis, Facultad de Ingeniería, Universidad Nacional Autónoma de México, Mexico City. 59 pp.

Bonilla-Barbosa J.R. and Viana-Lases J.A. 1997. Listados Florísticos de México XIV. Parque Nacional Lagunas de Zempoala. Instituto de Biología, Universidad Nacional Autónoma de México, Mexico City.

Cano-Santana Z. and Meave J. 1996. Sucesión primaria en derrames volcánicos: el caso del Xitle. Ciencias 41:58-68.

Castillo-Campos G., Dávila-Aranda P. and Zavala-Hurtado J.A. 2007. La selva baja caducifolia en una corriente de lava volcánica en el centro de Veracruz: lista florística de la flora vascular. Boletín de la Sociedad Botánica de México 80:77-104.

Cerros-Tlatilpa R. and Espejo-Serna A. 1998. Contribución al estudio florístico de los cerros El Sombrerito y Las Mariposas (Zoapapalotl) en el municipio de Tlayacapan, Morelos, México. Polibotánica 8:29-44.

Chao A. 1984. Nonparametric estimation of the number of classes in a population. Scandinavian Journal of Statistics 11:265-270.

Chao A. 1987. Estimating the population size for capture-recapture data with unequal catchability. Biometrics 43:783-791.
Colwell R.K. 2013. EstimateS: Statistical estimation of species richness and shared species from samples. Version 9. <http:// viceroy.eeb.uconn.edu/estimates/EstimateSPages/EstSUsersGuide/EstimateSUsersGuide.htm> (accessed December 10, 2013).

Cornejo-Tenorio G., Casas A., Farfán B., Villaseñor J.L. and Ibarra-Manríquez G. 2003. Flora y vegetación de las zonas núcleo de la Reserva de la Biosfera Mariposa Monarca, México. Boletín de la Sociedad Botánica de México 73:43-62.

Cornejo-Tenorio G. and Ibarra-Manríquez G. 2007. Plant reproductive phenology in a temperate forest of the Monarch Butterfly biosphere reserve, Mexico. Interciencia 32:445-452.

Christenhusz M.J.M., Reveal J.L., Farjon A., Gardner M.F., Mill R.R. and Chase M.W. 2011. A new classification and linear sequence of extant gymnosperms. Phytotaxa 19: 55-70.

Encina-Domínguez J.A., Zárate-Lupercio A., Valdés-Reyna J. and Villarreal-Quintanilla J.A. 2007. Caracterización ecológica y diversidad de los bosques de encino de la sierra de Zapalinamé, Coahuila, México. Boletín de la Sociedad Botánica de México 81:51-63.

Espinasa-Pereña R. 1999. Origen y evolución de tubos de lava en la Sierra Chichinautzin: el caso del volcán Suchiooc. M.Sc. Thesis. Instituto de Geofísica, Universidad Nacional Autónoma de México, Mexico City. 94 pp.

Espinosa-Garduño J. 1962. Vegetación de una corriente de lava de formación reciente, localizada en el declive meridional de la sierra Chichinautzin. Boletín de la Sociedad Botánica de México 27:67-114.

Facelli J.M. and Pickett S.T.A. 1991. Plant litter: its dynamics and effects on plant community structure. The Botanical Review 57:1-32.

Ferrusquía-Villafranca I. 1993. Geology of Mexico: a synopsis. In: Ramamoorthy T.P., Bye R., Lot A. and Fa J. Eds. Biological Diversity of Mexico: Origins and Distribution, pp. 3-107, Oxford University Press, New York.

Figueroa F. and Sánchez-Cordero V. 2008. Effectiveness of natural protected areas to prevent land use and land cover change in Mexico. Biodiversity and Conservation 17:3223-3240.

Flores-Castorena A. and Martínez-Alvarado D. 2010. Sinopsis florística. In: Bonilla-Barbosa J.R., Mora V.M., Luna-Figueroa J., Colín H. and Santillán-Alarcón S. Eds. Biodiversidad, Conservación y Manejo en el Corredor Biológico Chichinautzin: Condiciones Actuales y Perspectivas, pp. 69-97, Centro de Investigaciones Biológicas, Universidad Autónoma del Estado de Morelos, Cuernavaca.

Gentry A.H. and Dodson C. 1987. Contribution of nontrees to species richness of a tropical rain forest. Biotropica 19:149-156.

Hernández P. 1945. La flora maravillosa de Tepoztlán. Boletín de la Sociedad Botánica de México 3:13-15.

Hernández-Cárdenas R.A., Cerros-Tlatilpa R. and Flores-Morales A. 2014. Las plantas vasculares y vegetación de la barranca Tepecapa en el municipio de Tlayacapan, Morelos, México. Acta Botanica Mexicana 108: 11-38.

Holz I. 2006. Epiphytic communities of bryophytes and macrolichens in a Costa Rican montane oak forest. In: Kappelle M. Ed. Ecology and Conservation of Neotropical Montane Oak Forests, pp. 83-98, Springer, Berlin.

Huston M. 1980. Soil nutrients and tree species richness in Costa Rican forests. Journal of Biogeography 7:147-157.

Huston M.A. 1994. Biological Diversity: the Coexistence of Spe- 
cies on Changing Landscapes. Cambridge University Press, Cambridge.

INEGI [Instituto Nacional de Estadística y Geografía]. 2003. Cuaderno Estadístico Municipal de Tepoztlán, Morelos. Edición 2013. <http://www.inegi.org.mx/est/contenidos/espanol/sistemas/cem03/estatal/mor/m020/index.html> (accessed May 10, 2010).

Jost L. 2006. Entropy and diversity. Oikos 113:363-375.

Kappelle M., Kennis P.A.F. and de Vries R.A.J. 1995a. Changes in diversity along a successional gradient in a Costa Rican upper montane Quercus forest. Biodiversity and Conservation 4:10-34.

Kappelle M., Van Uffelen J.G. and Cleef A.M. 1995b. Altitudinal zonation of montane Quercus forests along two transects in Chirripó National Park, Costa Rica. Vegetatio 119:119-153.

Kitayama K., Mueller-Dombois D. and Vitousek P.M. 1995. Primary succession of Hawaiian montane rain forest on a chronosequence of eight lava flows. Journal of Vegetation Science 6:211-222.

Kottek M., Grieser J., Beck C., Rudolf B. and Rubel F. 2006. World Map of the Köppen-Geiger climate classification updated. Meteorologische Zeitschrift 15: 259-263.

Luna-José A.L., Montalvo-Espinosa L. and Rendón-Aguilar B. 2003. Los usos no leñosos de los encinos en México. Boletín de la Sociedad Botánica de México 72:107-117.

Luna-Vega I., Ocegueda-Cruz S. and Alcántara-Ayala O. 1994. Florística y notas biogeográficas del bosque mesófilo de montaña del municipio de Tlanchinol, Hidalgo, México. Anales del Instituto de Biología de la Universidad Nacional Autónoma de México, Serie Botánica 65:31-62.

Magurran A.E. 2004. Measuring Biological Diversity. Blackwell Science, Oxford.

Márquez A., Verma S.P., Anguita F., Oyarzun R. and Brandle J.L. 1999. Tectonics and volcanism of Sierra Chichinautzin: extension at the front of the Central Trans-Mexican Volcanic belt. Journal of Volcanology and Geothermal Research 93:125-150.

Martínez-Cruz J. and Téllez-Valdés O. 2004. Listado florístico de la sierra de Santa Rosa, Guanajuato, México. Boletín de la Sociedad Botánica de México 74:31-49.

Meave J.A., Rincón A. and Romero-Romero M.A. 2006. Oak forests of the hyper-humid region of La Chinantla, Northern Oaxaca range, Mexico. In: Kappelle M. Ed. Ecology and Conservation of Neotropical Montane Oak Forests, pp. 113-125, Springer, Berlin.

Meave J.A. and Pérez-García E. 2013. Vegetación: caracterización y factores que determinan su distribución. In: Márquez-Guzmán E., Collazo-Ortega M., Martínez-Gordillo M., Orozco-Segovia A. and Vázquez-Santana S. Eds. Biología de Angiospermas, pp. 470-477, Universidad Nacional Autónoma de México, Mexico City.

Medina-García C., Guevara-Féfer F., Martínez-Rodríguez M.A., Silva-Sáenz P., Chávez-Carbajal M.A. and García-Ruiz I. 2000. Estudio florístico en el área de la comunidad indígena de Nuevo San Juan Parangaricutiro, Michoacán, México. Acta Botanica Mexicana 52:5-41.

Mejía-Domínguez N.R., Meave J.A., Díaz-Ávalos C. and González E.J. 2011. Individual canopy-tree species effects on their immediate understory microsite and sampling community dynamics. Biotropica 43:572-581.

Mickel J.T. and Smith A.R. 2004. The pteridophytes of Mexico. Memoirs of The New York Botanical Garden 88:1-1054.
Mooney H.A. and J.R. Ehleringer. 1997. Photosynthesis. In: Crawley M.J. Ed. Plant Ecology, $2^{\text {nd }}$ ed., pp. 1-27, Blackwell Science, Cambridge.

Nixon K.C. 1993. The genus Quercus in Mexico. In: Ramamoorthy T.P., Bye R., Lot A. and Fa J. Eds. Biological Diversity of Mexico: Origins and Distribution, pp. 447-458, Oxford University Press, New York.

Nixon K.C. 2006. Global and Neotropical distribution and diversity of oak (genus Quercus) and oak forests. In: Kappelle M. Ed. Ecology and Conservation of Neotropical Montane Oak Forests, pp. 3-13, Springer, Berlin.

Oldfield S. and Eastwood A. 2007. The Red List of Oaks. Fauna \& Flora International, Cambridge.

Pulido M.T., Cavelier J. and Cortés-S. S.P. 2006. Structure and composition of Colombian montane oak forests. In: Kappelle M. Ed. Ecology and Conservation of Neotropical Montane Oak Forests, pp. 141-151, Springer, Berlin.

Pulido-Esparza V.A., Espejo-Serna A. and López-Ferrari A.R. 2009. Las monocotiledóneas nativas del Corredor Biológico Chichinautzin. Acta Botanica Mexicana 86:9-38.

R Development Core Team. 2010. R: A Language and Environment for Statistical Computing. The R Foundation for Statistical Computing, Viena.

Ramírez-Marcial N., Ochoa-Gaona S., González-Espinosa M. and Quintana-Ascencio P.F. 1998. Análisis florístico y sucesional en la estación biológica Cerro Huitepec, Chiapas, México. Acta Botanica Mexicana 44:59-85.

Reko B.P. 1945. Nombres botánicos de algunas plantas de Tepoztlán, Mor. Boletín de la Sociedad Botánica de México 2:17-18.

Rosenzweig M.L. 1995. Species Diversity in Space and Time. Cambridge University Press, Cambridge.

Rzedowski J. 1954. Vegetación del Pedregal de San Ángel (Distrito Federal, México). Anales de la Escuela Nacional de Ciencias Biológicas 8:59-129.

Rzedowski J. 2005. Relaciones geográficas y posibles orígenes de la flora. In: Rzedowski G.C. and Rzedowski J. Eds. Flora fanerogámica del Valle de México, $2^{\text {nd }}$ ed., pp. 24-29, Instituto de Ecología, A.C., Comisión Nacional para el Conocimiento y Uso de la Biodiversidad, Pátzcuaro.

Rzedowski G.C. and Rzedowski J. Eds. 2005. Flora fanerogámica del Valle de México. $2^{\text {nd }}$ ed. Instituto de Ecología, A.C., Comisión Nacional para el Conocimiento y Uso de la Biodiversidad, Pátzcuaro.

Santibáñez-Andrade G., Castillo-Argüero S., Zavala-Hurtado J.A., Martínez-Orea Y. and Hernández-Apolinar M. 2009. La heterogeneidad ambiental en un matorral xerófilo. Boletín de la Sociedad Botánica de México 85:71-79.

Schulze E.D., Beck E. and Müller-Hohenstein K. 2002. Plant Ecology. Springer, Berlin.

Siebe C., Rodríguez-Lara V., Schaaf P. and Abrams M. 2004. Radiocarbon ages of Holocene Pelado, Guespalapa, and Chichinautzin scoria cones, south of Mexico City: implications for archaeology and future hazards. Bulletin of Volcanology 66:203-225.

van der Maarel E. 1979. Transformation of cover-abundance values in phytosociology and its effects on community similarity. Vegetatio 39:97-114.

van der Maarel E. 2007. Transformation of cover-abundance values for appropriate numerical treatment - Alternatives to the proposals by Podani. Journal of Vegetation Science 18:767-770. 
Valencia-A. S. 2004. Diversidad del género Quercus (Fagaceae) en México. Boletín de la Sociedad Botánica de México 75:33-53.

Vega-Guzmán A., López-García J. and Manzo-Delgado L.L. 2008. Análisis espectral y visual de vegetación y uso del suelo con imágenes Landsat ETM+ con apoyo de fotografías aéreas digitales en el Corredor Biológico Chichinautzin, Morelos, México. Investigaciones Geográficas, Boletín del Instituto de Geografía 67:59-75.

Velázquez A. and Cleef A.M. 1993. The plant communities of the volcanoes "Tláloc" and "Pelado", México. Phytocoenologia 22:145-191.

Villaseñor J.L. 2004. Los géneros de plantas vasculares de la flora de
México. Boletín de la Sociedad Botánica de México 75:105-135. Waide R.B., Willig M.R., Steiner C.F., Mittelbach G., Gough L., Dodson S.I., Juday G.P. and Parmenter R. 1999. The relationship between productivity and species richness. Annual Review of Ecology and Systematics 30:257-300.

Walker L.R. and del Moral R. 2003. Primary Succession and Ecosystem Rehabilitation. Cambridge University Press, Cambridge.

Wolf J.H.D. and Flamenco-S. A. 2006. Vascular epiphytes and their potential as a conservation tool in pine-oak forests of Chiapas, México. In: Kappelle M. Ed. Ecology and Conservation of Neotropical Montane Oak Forests, pp. 375-391, Springer, Berlin.

Received: June 4th, 2014

Accepted: April 27th, 2015 
Appendix 1. People who helped in the identification of plant specimens, arranged by institution. Acronyms: FC-UNAM = Faculty of Sciences, Universidad Nacional Autónoma de México (UNAM); IB-UNAM = Institute of Biology, UNAM; FESI-UNAM = Faculty of Higher Studies at Iztacala, UNAM; FB-UAEM = Faculty of Biology, Universidad Autónoma del Estado de Morelos; CUCBAUdeG = Center for Biological Sciences, Agriculture and Livestock Industry, Universidad de Guadalajara.

\author{
Institution and name \\ FB-UAEM \\ Rodrigo Hernández Cárdenas \\ CUCBA-UdeG \\ Aarón Rodríguez Contreras \\ IB-UNAM \\ Alfonso Delgado Salinas \\ Eduardo Domínguez Licona \\ Hilda Flores Olvera \\ María del Rosario García Peña \\ Oscar Hinojosa Espinosa \\ Verónica Juárez Jaimes \\ Esteban Martínez Salas \\ Gilda Ortiz Calderón \\ Jaime Pacheco Trejo \\ Angélica Ramírez Roa \\ Clara Hilda Ramos Álvarez \\ Alberto Reyes García \\ Gerardo Adolfo Salazar Chávez \\ Jorge Sánchez Ken
}

IB-UNAM (continues)

Rafael Torres Colín

José Luis Villaseñor Ríos

Leticia Torres Colín

FC-UNAM

Sebastián Block Munguía

Ramiro Cruz Durán

Nelly Diego Pérez

Jaime Jiménez Ramírez

Lucio Lozada Pérez

Martha Martínez Gordillo

Eduardo Alberto Pérez García

Jorge Rojas Gutiérrez

Jesús Ricardo de Santiago Pérez

Susana Valencia Ávalos

Ernesto Velázquez Montes

FESI-UNAM

Rafael Lira Saade 
Appendix 2. Checklist of vascular plant taxa from the oak forests of El Tepozteco National Park (Morelos, Mexico). Reference vouchers were deposited at MEXU, at FCME [Herbarium of the Faculty of Sciences, Universidad Nacional Autónoma de México (UNAM) (indicated with the herbarium's code next to voucher number)] or, for vouchers lacking reproductive structures or of few value for a collection, in the plant collection kept at the Plant Ecology and Diversity Laboratory of the Faculty of Sciences, UNAM (indicated with an asterisk). The geomorphological units where each taxon was recorded are also shown. Abbreviations for geomorphological units: $\mathrm{CH}=$ Chichinautzin, $\mathrm{SU}=$ Suchiooc, $\mathrm{UO}=$ upper Otates, $\mathrm{LO}=$ lower Otates, OC = Oclayuca, TE = El Tepozteco Range.

\begin{tabular}{|c|c|c|c|c|c|c|}
\hline & $\mathrm{CH}$ & SU & UO & LO & OC & TE \\
\hline \multicolumn{7}{|l|}{ LYCOPODIOPHYTA } \\
\hline $\begin{array}{l}\text { Selaginella pallescens (C.Presl) Spring } \\
\text { SB } 1238\end{array}$ & $x$ & $x$ & & $x$ & & $x$ \\
\hline $\begin{array}{l}\text { Selaginella aff. porphyrospora A.Braun } \\
\text { SB 859* }\end{array}$ & & & $x$ & & & \\
\hline \multicolumn{7}{|l|}{ POLYPODIOPHYTA } \\
\hline \multicolumn{7}{|l|}{ Aspleniaceae Newman } \\
\hline $\begin{array}{l}\text { Asplenium castaneum Schltdl. \& Cham. } \\
\qquad \text { SB } 1254\end{array}$ & & & & & & $x$ \\
\hline $\begin{array}{l}\text { Asplenium hallbergii Mickel \& Beitel } \\
\qquad \text { SB } 817\end{array}$ & $x$ & & $x$ & & & \\
\hline $\begin{array}{l}\text { Asplenium monanthes L. } \\
\qquad \text { SB } 293\end{array}$ & $x$ & $x$ & $x$ & & $X$ & \\
\hline $\begin{array}{l}\text { Asplenium praemorsum Sw. } \\
\qquad \text { SB } 14\end{array}$ & $x$ & & & & & \\
\hline \multicolumn{7}{|l|}{ Dennstaedtiaceae Lotsy } \\
\hline $\begin{array}{l}\text { Pteridium aquilinum (L.) Kuhn var. arachnoideum (Kaulf.) Brade } \\
\text { SB } 1262^{*}\end{array}$ & & & & & & $x$ \\
\hline \multicolumn{7}{|l|}{ Dryopteridaceae Herter } \\
\hline $\begin{array}{l}\text { Dryopteris cinnamomea (Cav.) C.Chr. } \\
\quad \text { SB } 912\end{array}$ & $x$ & & & $x$ & & $x$ \\
\hline $\begin{array}{l}\text { Dryopteris maxonii Underw. \& C.Chr. } \\
\text { SB } 1273\end{array}$ & $x$ & $x$ & & & & $x$ \\
\hline $\begin{array}{l}\text { Dryopteris patula (Sw.) Underw. } \\
\quad \text { SB } 1119\end{array}$ & $x$ & & & & & $x$ \\
\hline $\begin{array}{l}\text { Polystichum rachichlaena Fée } \\
\qquad \text { SB } 623\end{array}$ & & & & & $x$ & \\
\hline \multicolumn{7}{|l|}{ Ophioglossaceae Martinov } \\
\hline $\begin{array}{l}\text { Botrychium virginianum (L.) Sw. } \\
\text { SB } 834\end{array}$ & & & & $x$ & & \\
\hline Polypodiaceae J. Presl & & & & & & \\
\hline $\begin{array}{l}\text { Pecluma ferruginea (M.Martens \& Galeotti) M.G.Price } \\
\qquad \text { SB } 764\end{array}$ & & & & & & $x$ \\
\hline $\begin{array}{l}\text { Phlebodium pseudoaureum (Cav.) Lellinger } \\
\quad \text { SB } 353\end{array}$ & $x$ & & $\mathrm{x}$ & $x$ & & $x$ \\
\hline $\begin{array}{l}\text { Pleopeltis mexicana (Fée) Mickel \& Beitel } \\
\text { SB 587* }\end{array}$ & $x$ & & & & & \\
\hline $\begin{array}{l}\text { Pleopeltis polylepis (Roemer ex Kunze) T.Moore } \\
\text { SB } 1358\end{array}$ & & & & $x$ & & $x$ \\
\hline $\begin{array}{l}\text { Polypodium furfuraceum Schltdl. \& Cham. } \\
\text { SB } 748\end{array}$ & & & & $x$ & & $\mathrm{X}$ \\
\hline $\begin{array}{l}\text { Polypodium hartwegianum Hook. } \\
\qquad \text { SB } 1044\end{array}$ & $x$ & & & & & \\
\hline $\begin{array}{l}\text { Polypodium madrense J.Sm. } \\
\qquad \text { SB } 1140\end{array}$ & $x$ & $x$ & $\mathrm{X}$ & $x$ & $x$ & $\mathrm{X}$ \\
\hline
\end{tabular}


Appendix 2. Continuation.

$\begin{array}{llllll}\mathrm{CH} & \mathrm{SU} & \mathrm{HO} & \mathrm{LO} & \mathrm{OC} & \mathrm{TE}\end{array}$

Polypodium plesiosorum Kunze SB 29

Polypodium polypodioides Weath. SB 1297

Polypodium rosei Maxon SB 1118

Polypodium subpetiolatum Hook. SB 818

Pteridaceae E.D.M. Kirchn

Adiantum andicola Liebm. SB 1215

Adiantum braunii Mett. ex Kuhn SB $761^{*}$

Adiantum concinnum Humb. \& Bonpl. ex Willd. SB 1280

Adiantum poiretii Wikstr. SB 1067

Adiantum raddianum C.Presl X SB 533

Anogramma leptophylla (L.) Link SB 95

Bommeria pedata (Sw.) E.Fourn. SB 876*

Cheilanthes bonariensis (Willd.) Proctor SB 334

Cheilanthes cuneata Kaulf. ex Link SB 1275

Cheilanthes farinosa (Forssk.) Kaulf. SB 1087

Cheilanthes kaulfussii Kunze SB 1314

Cheilanthes lendigera (Cav.) Sw. SB 332

Cheilanthes marginata Kunth SB 1313*

Cheilanthes myriophylla Desv. SB 1256

Cheilanthes pyramidalis Fée SB 697*

Notholaena ochracea (Hook.) Yatsk. \& Arbeláez SB 1319

Pellaea ternifolia (Cav.) Link SB 331

Pteris quadriaurita Retz. SB $1262 *$

Woodsiaceae Herter

Woodsia mollis (Kaulf.) J.Sm. SB 931

GYMNOSPERMAE

Cupressaceae Bartl.

Juniperus flaccida Schltdl.

SB $41^{*}$

$x \quad x$

X

$X$

X

X

X

$X$

$X$

$X$

X

$$
\text { X }
$$

$X$

$\begin{array}{ll}x & x \\ x & x\end{array}$

X

X

X

$X$

$X$

$x-x$

X

$X$

$X$

$X$

X

$x \quad x \quad x$

$X$

X

$x$

$x$

$X$

$x$

X

X

$x$

X 
Appendix 2. Continuation.

$\begin{array}{llllll}\mathrm{CH} & \mathrm{SU} & \mathrm{UO} & \mathrm{LO} & \mathrm{OC} & \mathrm{TE}\end{array}$

Pinaceae Lindl.

Pinus aff. ayacahuite C.Ehrenb. ex Schltdl. SB 1352*

Pinus aff. hartwegii Lindl. SB 1020*

Pinus aff. leiophylla Schiede ex Schltdl. \& Cham. SB 514*

Pinus aff. maximinoi H.E.Moore SB 248*

Pinus aff. montezumae Lamb. SB 1054*

Pinus aff. pseudostrobus Lindl. SB 1173*

Pinus aff. teocote Schltdl. \& Cham. SB 1327*

ANGIOSPERMAE: MAGNOLIOPSIDA

Actinidiaceae Gilg \& Werderm.

Saurauia sp.

SB 325*

Adoxaceae E. Mey.

Sambucus sp.

SB 1376*

Amaranthaceae Juss.

Iresine diffusa Humb. \& Bonpl. ex Willd. SB 821

Iresine sp.

SB 1164*

Anacardiaceae R.Br.

Toxicodendron radicans (L.) Kuntze SB 612*

Annonaceae Juss.

Annona cherimola Mill. SB 894*

Apiaceae Lindl.

Arracacia tolucensis (Kunth) Hemsl. SB 1022*

Donnellsmithia mexicana (B.L.Rob.) Mathias \& Constance SB 924

Eryngium cf. ghiesbreghtii Decne.

SB 727

Eryngium cf. pectinatum C.Presl ex DC.

SB 57

X

$\begin{array}{lll}x & x \\ x & x \\ x & x \\ x & x\end{array}$

$x$

$x$

$X$

Apocynaceae Juss.

Asclepias pringlei (Greenm.) Woodson SB 1086*

Mandevilla sp.

SB 731

Gonolobus uniflorus Kunth SB 1045

$x$

$x$

Araliaceae Juss.

Oreopanax peltatus Linden

$X$

X 
Appendix 2. Continuation.

CH SU UO LO OC TE

Asteraceae Bercht. \& J.PresI

Acourtia sp1.

SB 430

Acourtia sp2.

SB 60*

Ageratina areolaris (DC.) Gage ex B.L.Turner

SB 837

Ageratina choricephala (B.L.Rob.) R.M.King \& H.Rob.

SB 1283

Ageratina glabrata (Kunth) R.M.King \& H.Rob.

SB 163

Ageratina mairetiana (DC.) R.M.King \& H.Rob.

SB 1010

Ageratina pazcuarensis (Kunth) R.M.King \& H.Rob.

SB 1093

Ageratina aff. petiolaris (Moc. ex DC.) R.M.King \& H.Rob.

SB 1059

Ageratina photina (B.L. Rob.) R.M.King \& H.Rob.

SB 520

Ageratum corymbosum Zuccagni

SB 525

Alloispermum scabrum (Lag.) H.Rob.

SB 1304

Archibaccharis serratifolia (Kunth) S.F.Blake

SB 1136

Baccharis conferta Kunth

SB 1208

Bidens ocellatus (Greenm.) Melchert

SB 196

Bidens sp1.

SB 745

Brickellia scoparia (DC.) A.Gray var. scoparia SB 1317

Coreopsis rhyacophila Greenm.

$X$

$x$

$X$

$X$

X $\quad X$

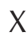

X

X $\quad X$

$x \quad x \quad x \quad x$

SB 598

Cosmos crithmifolius Kunth

SB 1346

Critoniopsis salicifolia (DC.) H.Rob.

SB 1300

Dahlia coccinea Cav.

SB 595

Dahlia merckii Lehm.

$X$

$X$

X

X

X $\quad X$

$x$

X

$X$

$X$

SB 1008

Dahlia rudis Sørensen

SB 566a

Eupatorium collinum DC.

SB 878

Hieracium sp1.

SB 1267*

Jaegeria hirta (Lag.) Less.

SB 578

X

X

X $\quad X$

X $\quad X$

X

X

X

X

X

X $\quad X$

X

X

$X$

X

X 
Appendix 2. Continuation.

$\begin{array}{llllll}\mathrm{CH} & \mathrm{SU} & \mathrm{UO} & \text { LO } & \text { OC } & \text { TE }\end{array}$

Lagascea rigida (Cav.) Stuessy

SB 1311

Melampodium montanum Benth var. viridulum Stuessy

SB 1138

Montanoa frutescens (Mairet ex DC.) Hemsl.

SB 218

Psacalium peltatum (Kunth) Cass. var. peltatum SB 836

Pseudognaphalium attenuatum var. silvicola Anderb. SB 1007

Pseudognaphalium liebmannii var. monticola (Sch.Bip. ex Klatt) Anderb. $\quad$ X SB 1012

Pseudognaphalium oxyphyllum (DC.) Kirp. SB 541

Pseudognaphalium roseum (Kunth) Anderb. SB 599

Roldana albonervia (Greenm.) H.Rob. \& Brettell SB 277

Roldana angulifolia (DC.) H.Rob. \& Brettell SB 1091

Roldana chapalensis (S.Watson) H.Rob. \& Brettell SB 644

Roldana lineolata (DC.) H.Rob. \& Brettell SB 477

Roldana lobata La Llave SB 544

Roldana suffulta (Greenm.) H.Rob. \& Brettell SB 1341

Roldana sp1.

SB 559*

Rumfordia floribunda DC. var. floribunda SB 1359

Smallanthus maculatus (Cav.) H.Rob. SB 641

Stevia aschenborniana Sch.Bip. SB 1269

Stevia monardifolia Kunth SB 1196

Stevia origanoides Kunth SB 879

Stevia ovata Willd. SB 391

Stevia suaveolens Lag. SB 1212

Stevia subpubescens Lag. var. subpubescens SB 1018

Tagetes filifolia Lag. SB 402

Tagetes lucida Cav. SB 105

Tagetes lunulata Ortega SB 404

$x$

X

X

$X$

X

X $\quad x$

$X$

X

$X$

$x \quad x \quad x$

X

X

X $\quad X$

X
X

X

$X$

X

X

X $x$

\section{X}

X

X

X

$X$

$X$

$X$

$X$

$$
x
$$

$x$

$x$

X

$x$ 
Appendix 2. Continuation.

$\begin{array}{llllll}\mathrm{CH} & \mathrm{SU} & \mathrm{UO} & \mathrm{LO} & \mathrm{OC} & \text { TE }\end{array}$

Tridax brachylepis Hemsl.

SB 1312

Trigonospermum melampodioides DC.

SB 1344

Verbesina fastigiata B.L.Rob. \& Greenm.

SB 1263

Verbesina oncophora B.L.Rob. \& Seaton var. oncophora SB 1103

Verbesina virgata Cav. var. virgata

SB 219

Viguiera dentata (Cav.) Spreng. SB 1279

Begoniaceae C. Agardh

Begonia cf. balmisiana Balmis SB 604*

Begonia gracilis Kunth SB 10

Betulaceae Gray

Alnus acuminata Kunth SB $617^{*}$

Alnus jorullensis Kunth

SB 1066*

Bignoniaceae Juss.

Tecoma stans (L.) Juss. ex Kunth SB $45^{*}$

Boraginaceae Juss.

Lithospermum trinervium (Lehm.) J.Cohen

SB 1229

Nama origanifolia Kunth

SB 1259

Tournefortia cf. acutiflora M.Martens \& Galeotti

SB 739

Wigandia urens (Ruiz \& Pav.) Kunth

SB $1143^{*}$

Cactaceae Juss.

Heliocereus speciosus (Cav.) Britton \& Rose subsp. speciosus SB 547

Campanulaceae Juss.

Lobelia laxiflora Kunth SB 683*

Lobelia schmitzii E.Wimm.

$x-x$

X

X $\quad X$

$X$

X

$X$

X

X

X $\quad X$

$X$

X

$X$

$X$

X $\quad X$

X

$X$

$X$

X

X

$X$

X SB 26a

Caprifoliaceae Juss.

Symphoricarpos microphyllus Kunth SB 1234*

Valeriana robertianifolia Briq. SB 483

Valeriana sorbifolia var. mexicana (DC.) F.G.Mey.

SB 503

Valeriana urticifolia Kunth

$X \quad X \quad X \quad X \quad X$

SB 129

x $x$

\section{X}

X

X 
Appendix 2. Continuation.

$\begin{array}{llllll}\mathrm{CH} & \mathrm{SU} & \mathrm{UO} & \mathrm{LO} & \mathrm{OC} & \mathrm{TE}\end{array}$

\section{Caryophyllaceae Juss.}

Arenaria lanuginosa (Michx.) Rohrb.

$X \quad X \quad X$

SB 856

Drymaria glandulosa Bartl.

SB 762

Drymaria villosa Schltdl. \& Cham.

SB 1025

Minuartia moehringioides (Moc. \& Sessé ex DC.) Mattf. SB 1001

Stellaria cuspidata Willd. ex Schltdl.

SB 1230

Celastraceae R. Br.

Celastrus pringlei Rose

SB 305*

Clethraceae Klotzsch

Clethra mexicana DC.

SB 1000

Convolvulaceae Juss.

Ipomoea aff. caudata Fernald SB 654

Ipomoea aff. murucoides Roem. \& Schult. SB 890*

Ipomoea purpurea (L.) Roth SB 113

Crassulaceae J. St.-Hil.

Echeveria gibbiflora Moc. \& Sessé ex DC.

(No specimens of this species were collected)

Sedum frutescens Rose SB 6*

Sedum jaliscanum S.Watson SB 899

Sedum oxypetalum Kunth SB 289*

Cucurbitaceae Juss.

Cyclanthera integrifoliola Cogn. SB 1165

Sechiopsis triqueter (Ser.) Naudin SB 1282

Ericaceae Juss.

Arbutus xalapensis Kunth SB 154*

Comarostaphylis glaucescens (Kunth) Zucc. ex Klotzsch SB 387

Euphorbiaceae Juss.

Acalypha langiana Müll.Arg. SB 52

Acalypha aff. triloba Müll.Arg. SB 118

Acalypha sp. SB 246*

Euphorbia ariensis Kunth

$X$

X

$X$

X

$X$

X

X

$x$

X

$$
\begin{aligned}
& x \\
& x
\end{aligned}
$$

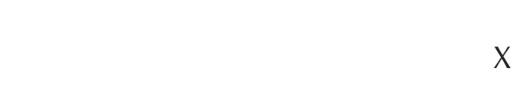

$X$

SB 1251 
Appendix 2. Continuation.

\begin{tabular}{|c|c|c|c|c|c|}
\hline & $\mathrm{CH}$ & SU & UO & LO & OC \\
\hline $\begin{array}{l}\text { Euphorbia sonorae Rose } \\
\text { SB 1287a [FCME] }\end{array}$ & & & & $x$ & \\
\hline $\begin{array}{l}\text { Euphorbia subreniformis S.Watson } \\
\qquad \text { SB } 874\end{array}$ & & & & $x$ & \\
\hline
\end{tabular}

\section{Fabaceae Lindl.}

Acacia pennatula (Schltdl. \& Cham.) Benth. SB $101^{*}$

Acaciella angustissima (Mill.) Britton \& Rose var. angustissima SB 674

Acaciella painteri Britton \& Rose var. houghii L.Rico SB 456*

Astragalus guatemalensis Hemsl. var. brevidentatus Barneby SB 1340

Brongniartia lupinoides (Kunth) Taub. SB 1285

Calliandra grandiflora (L'Hér.) Benth. SB 1247

Canavalia villosa Benth. SB 104

Cologania broussonetii (Balb.) DC. SB 677

Crotalaria vitellina KerGawl.

$\begin{array}{lll}x & x \\ x & x & x \\ x & x & x \\ x & x & x \\ x & x & x \\ x & x & x \\ & x & x\end{array}$

Dalea reclinata (Cav.) Willd.

X

$X$ SB 109

Desmodium bellum (S.F.Blake) B.G.Schub. SB 1240

Desmodium aff. cinereum (Kunth) DC. SB 1332*

Desmodium aff. densiflorum Hemsl. SB 729*

Desmodium intortum (Mill.) Urb.

SB 111

Desmodium aff. jaliscanum S.Watson SB $467^{*}$

Desmodium sp. SB 372*

Erythrina breviflora Sessé \& Moc. ex DC. SB 567

Eysenhardtia orthocarpa (A.Gray) S.Watson SB 1330*

Indigofera thibaudiana DC. SB 106

Lupinus aff. elegans Kunth SB 1207

Lysiloma divaricatum (Jacq.) J.F.Macbr. SB 778*

Mimosa albida Humb. \& Bonpl. ex Willd. SB 871

Mimosa caerulea Rose SB 1135* 
Appendix 2. Continuation.

\begin{tabular}{|c|c|c|c|c|c|c|}
\hline & $\mathrm{CH}$ & SU & UO & LO & OC & TE \\
\hline $\begin{array}{l}\text { Phaseolus coccineus L. } \\
\text { SB } 930\end{array}$ & $x$ & $x$ & & $X$ & $X$ & $X$ \\
\hline $\begin{array}{l}\text { Phaseolus leptostachyus Benth. } \\
\text { SB } 884\end{array}$ & & & & $x$ & & \\
\hline $\begin{array}{l}\text { Phaseolus vulgaris L. } \\
\text { SB } 820\end{array}$ & & & $x$ & $X$ & & \\
\hline $\begin{array}{l}\text { Trifolium amabile Kunth } \\
\qquad \text { SB } 126\end{array}$ & & & & $X$ & & \\
\hline $\begin{array}{l}\text { Vachellia campechiana (Mill.) Seigler \& Ebinger } \\
\text { SB 1290* }\end{array}$ & & & & & & $x$ \\
\hline \multicolumn{7}{|l|}{ Fagaceae Dumort. } \\
\hline $\begin{array}{l}\text { Quercus castanea Née } \\
\text { SB } 226\end{array}$ & & $X$ & $\mathrm{X}$ & $X$ & & $\mathrm{X}$ \\
\hline $\begin{array}{l}\text { Quercus glabrescens Benth. } \\
\text { SB } 91[\mathrm{FCME}]\end{array}$ & & & & $x$ & & \\
\hline $\begin{array}{l}\text { Quercus glaucoides M.Martens \& Galeotti } \\
\text { SB } 718 \text { [FCME] }\end{array}$ & & & & & & $x$ \\
\hline $\begin{array}{l}\text { Quercus laurina Bonpl. } \\
\qquad \text { SB } 561\end{array}$ & & & $x$ & & $X$ & \\
\hline $\begin{array}{l}\text { Quercus obtusata Bonpl. } \\
\text { SB } 892\end{array}$ & & & & $X$ & & $x$ \\
\hline $\begin{array}{l}\text { Quercus rugosa Née } \\
\text { SB } 1\end{array}$ & $x$ & $x$ & $x$ & & & $x$ \\
\hline Garryaceae Lindl. & & & & & & \\
\hline $\begin{array}{l}\text { Garrya laurifolia Hartw. ex Benth. } \\
\text { SB 386* }\end{array}$ & $x$ & & $x$ & $X$ & & $x$ \\
\hline Geraniaceae Juss. & & & & & & \\
\hline $\begin{array}{l}\text { Geranium seemannii Peyr. } \\
\qquad \text { SB } 1046\end{array}$ & & $\mathrm{X}$ & $x$ & $X$ & $x$ & \\
\hline $\begin{array}{l}\text { Gesneriaceae Rich. \& Juss. } \\
\text { Achimenes heterophylla (Mart.) DC. }\end{array}$ & & & & & & $x$ \\
\hline
\end{tabular}

$$
\text { SB 565a }
$$

Grossulariaceae DC.

Ribes sp.

SB 1028*

Hypericaceae Juss.

Hypericum philonotis Schltdl. \& Cham. SB 535

Lamiaceae Martinov

Asterohyptis stellulata (Benth.) Epling SB 116 [FCME]

Cunila lythrifolia Benth. SB 1201

Hyptis mutabilis (Rich.) Briq. SB 107 [FCME]

Lepechinia caulescens (Ortega) Epling SB 1199 [FCME]

Lepechinia sp1. 1210*

Salvia gesneraeflora Lindl. \& Paxton SB 1183 
Appendix 2. Continuation.

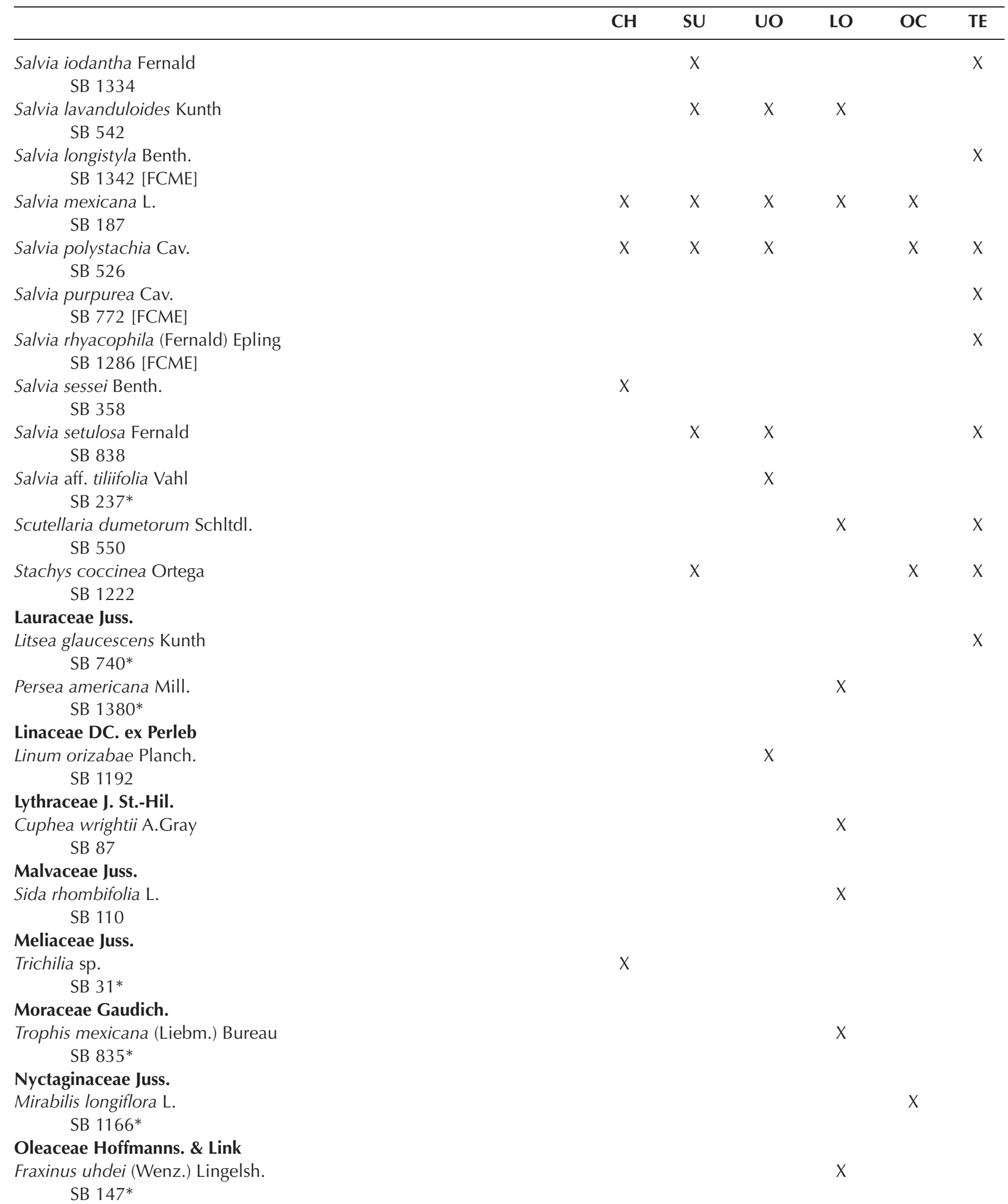


Appendix 2. Continuation.

$\begin{array}{llllll}\text { CH SU } & \text { UO } & \text { LO } & \text { OC } & \text { TE }\end{array}$

Onagraceae Juss.

Lopezia racemosa Cav.

SB 566

Fuchsia thymifolia Kunth subsp. thymifolia SB 1169

Fuchsia sp1.

SB 614*

Oxalidaceae R.Br.

Oxalis aff. hernandezii DC. SB 796*

Oxalis aff. jacquiniana Kunth SB 500*

Oxalis aff. tetraphylla Cav. SB 652*

Orobanchaceae Vent.

Castilleja aff. stipifolia G.L.Nesom SB 400*

Castilleja tenuiflora Benth. SB 605

Papaveraceae Juss.

Bocconia aff. arborea S.Watson SB 888*

Passifloraceae Juss. ex Roussel

Passiflora cf. exsudans Zucc. SB 465*

Pentaphylacaceae Engl.

Ternstroemia lineata DC. subsp. lineata SB 1080

Phytolaccaceae R.Br.

Phytolacca rivinoides Kunth \& C.D.Bouché SB 549

Piperaceae Giseke

Peperomia bracteata A.W.Hill SB 428*

Peperomia galioides Kunth SB 34

Peperomia hispidula (Sw.) A.Dietr. SB 291

Plantaginaceae Juss.

Lophospermum scandens D.Don SB 574

Penstemon roseus (Cerv. ex Sweet) G.Don SB 158

Russelia coccinea (L.) Wettst. SB 732

Polygalaceae Hoffmanns. \& Link

Monnina ciliolata Sessé \& Moc. ex DC.

$\begin{array}{llllll}X & X & X & x & X & x \\ x & x & x & x & x \\ & & x & \end{array}$

$\begin{array}{cccc}X & x & x \\ X & x & x\end{array}$

X

X SB 532

Primulaceae Batsch ex Borkh.

Anagallis arvensis $\mathrm{L}$.

X $\quad X \quad X$

$X$

X $\quad X \quad X \quad X$

SB 648* 
Appendix 2. Continuation.

$\begin{array}{llllll}\mathrm{CH} & \mathrm{SU} & \mathrm{UO} & \mathrm{LO} & \mathrm{OC} & \mathrm{TE}\end{array}$

Ranunculaceae Juss.

Clematis dioica L. SB 702

Delphinium pedatisectum Hemsl. SB 649

Thalictrum gibbosum Lecoy. SB 274*

Thalictrum grandifolium S.Watson SB 553

Rosaceae Juss.

Alchemilla procumbens Rose SB 1048

Rubus cf. cymosus Rydb. SB 1197*

Rubus pringlei Rydb. X $\quad X$

$X$

X

X SB 308

Prunus aff. serotina Ehrh.

$x$ X

X SB 728*

Rubiaceae Juss.

Borreria remota (Lam.) Bacigalupo \& E.L.Cabral SB 54

Bouvardia ternifolia (Cav.) Schltdl. SB 1307

Crusea coccinea DC. var. coccínea SB 266*

Crusea longiflora (Willd. ex Roem. \& Schult.) W.R.Anderson SB 811

Crusea sp1. SB $1071 *$

Didymaea mexicana Hook.f. SB 507*

Galium aschenbornii Nees \& S. Schauer SB 1006

Hoffmannia conzattii B.L.Rob. SB 632*

Mitracarpus sp. SB 1182*

Sabiaceae Blume

Meliosma dentata (Liebm.) Urb. SB 1186*

Salicaceae Mirb.

Xylosma flexuosa (Kunth) Hemsl. SB $61^{*}$

Sapindaceae Juss.

Dodonaea viscosa Jacq. SB 46

Serjania triquetra Radlk. SB 872*

Scrophulariaceae Juss.

Buddleja cordata Kunth SB 1046a

$\begin{array}{ll}X & X \\ X & X\end{array}$

X $\quad x$

$X$

X

\section{X}

X $\quad X$

X

X $\quad X$

X

$x$


Appendix 2. Continuation.

$\begin{array}{llllll}\mathrm{CH} & \mathrm{SU} & \mathrm{UO} & \mathrm{LO} & \mathrm{OC} & \mathrm{TE}\end{array}$

Buddleja parviflora Kunth SB 1100

Buddleja cf. sessiliflora Kunth SB 1097

Solanaceae Juss.

Cestrum anagyris Dunal SB 1090*

Cestrum nitidum M.Martens \& Galeotti SB 1205*

Cestrum nocturnum L. SB 638*

Cestrum oblongifolium Schltdl. SB 564*

Cestrum thyrsoideum Kunth SB 1343*

Cestrum tomentosum L.f. SB $317^{*}$

Jaltomata procumbens (Cav.) J.L.Gentry SB 1065*

Lycianthes lenta (Cav.) Bitter SB 462*

Solanum aligerum Schltdl. SB 1178*

Solanum appendiculatum Dunal SB 634*

Solanum nigrescens M.Martens \& Galeotti SB 551*

Solanum nigricans M.Martens \& Galeotti SB 1189*

Solanum stoloniferum Schltdl. \& Bouché SB 943*

\section{Staphyleaceae Martinov}

Turpinia aff. paniculata Vent. SB $1376^{*}$

Styracaceae DC. \& Spreng.

Styrax ramirezii Greenm. SB 135*

Symplocaceae Desf.

Symplocos citrea Lex. ex La Llave \& Lex. SB 252*

Verbenaceae J.St.-Hil.

Lantana camara L. SB 873

Lantana velutina M.Martens \& Galeotti SB 548

Lippia mexicana Grieve SB 678

Violaceae Batsch

Viola aff. guatemalensis W. Becker SB 1194

\section{$X$}

X $\quad X$

$X \quad X$

$X$

$X$

X $\quad X$

$X$

$X$

X

X

X

X

X

\section{$x$}

$X \quad X$

X

X

$X$

X

X

X

$$
\text { X }
$$

X

X $\quad$ X

X

$X$

$X$

X 
Appendix 2. Continuation.

CH SU UO LO OC $\quad$ TE

\section{Vitaceae Juss.}

Vitis aff. tiliifolia Humb. \& Bonpl. ex Roem \& Schult. SB 620*

ANGIOSPERMAE: LILIOPSIDA

Alstroemeriaceae Dumort.

Bomarea edulis (Tussac) Herb.

SB 307

Amaryllidaceae J.St.-Hil.

Hymenocallis aff. glauca (Zucc.) M.Roem. SB 724*

Manfreda pringlei Rose SB 885*

Manfreda pubescens (Regel \& Ortgies) Verh.-Will. ex Pina SB 1284*

Araceae Juss.

Syngonium neglectum Schott SB 758

Asparagaceae Juss.

Agave aff. angustifolia Haw. SB 341

Agave horrida Lem. ex Jacobi SB $347^{*}$

Agave aff. inaequidens K.Koch SB 1017

Echeandia mexicana Cruden SB 920

Echeandia sp1. SB 659*

Bromeliaceae Juss.

Hechtia podantha Mez SB 354*

Pitcairnia cf. heterophylla (Lindl.) Beer SB 352*

Tillandsia cf. bourgaei Baker

$\begin{array}{lllll}X & X & X & X\end{array}$

SB 336*

Commelinaceae Mirb.

Commelina cf. leiocarpa Benth. SB 712

Commelina tuberosa L. SB 686

Tinantia erecta (Jacq.) Schltdl. SB 765

Tradescantia poelliae D.R.Hunt SB 651

Cyperaceae Juss.

Cyperus seslerioides Kunth SB 660

Cyperus hermaphroditus (Jacq.) Standl. SB 1260

Cyperus sp1. SB $497 *$

X

X

$x$

X

$X$

$X$

X

X

$X$

X

X

X

X

X $\quad$ X
X

$X$

$X$

X

$X$

X

X

X

$$
\text { X }
$$<smiles>C1CCC1</smiles><smiles>C1CCC1</smiles><smiles>C1CCCC1</smiles>

X

X

$x$

X

X

X 
Appendix 2. Continuation.

$\begin{array}{llllll}\text { CH SU UO } & \text { LO } & \text { OC } & \text { TE }\end{array}$

Dioscoreaceae R.Br.

Dioscorea galeottiana Kunth SB 752

Dioscorea cf. urceolata Uline SB 1031

Hypoxidaceae R.Br.

Hypoxis sp1. SB 349*

Iridaceae Juss.

Sisyrinchium angustissimum (B.L.Rob. \& Greenm.) Greenm. \& C.H.Thomps. X SB 388

Orchidaceae Juss.

Aulosepalum aff. pyramidale (Lindl.) M.A.Dix \& M.W.Dix SB 245*

Bletia sp1.

SB 1029*

Epidendrum matudae L.O.Williams SB 330

Govenia sp1. SB 260*

Malaxis fastigiata (Rchb.f.) Kuntze SB 936

Malaxis rosilloi R.González \& E.W.Greenw. SB 768

Sarcoglottis sp1. SB 139

\section{Poaceae Banhart}

Brachypodium mexicanum (Roem. \& Schult.) Link SB 1200

Briza minor L.

X

X

X

x


Appendix 2. Continuation.

\section{$\mathrm{CH}$}

SU

UO

Oplismenus burmannii (Retz.) P.Beauv. var. burmannii SB 62

Oplismenus hirtellus (L.) P.Beauv. SB 893

Paspalum prostratum Scribn. \& Merr. SB 27*

Paspalum squamulatum E.Fourn. SB 119

Piptochaetium virescens (Kunth) Parodi SB 447

Vulpia myuros (L.) C.C.Gmel.

SB 407

Zuloagaea bulbosa (Kunth) Bess

SB 1145*

Smilacaceae Vent.

Smilax aff. moranensis M.Martens \& Galeotti SB 619* 